\title{
Reconsidering the syntax of interrogatives in Caribbean Spanish, with special reference to Dominican Spanish
}

\author{
Michael Zimmermann \\ University of Konstanz \\ michael.zimmermann@uni-konstanz.de
}

Received: 04-10-2017

Accepted: 06-03-2019

\begin{abstract}
This paper readdresses one of the most conspicuous syntactic traits of varieties of Caribbean Spanish that has been on the research agenda ever since almost a hundred years ago: the preverbal occurrence of subjects in interrogatives with a fronted simple non-subject argumental wh-expression. In an attempt to shed more light on the still highly controversial issues of the frequency of $w h \mathrm{SV}$ order and the kind(s) of preverbal subject, the present paper initially gathers claims regarding these issues as well as examples from the literature and then presents the corresponding results from a refined large-scale quantitative analysis of natural speech from colloquial Dominican Spanish, hereby filling a long-standing lacuna. Furthermore, the paper discusses previous approaches and shows that none of these are free from problems. Drawing on relevant aspects of earlier approaches and building on insights into the morpho-syntactic status of subject pronouns as well as word order in medieval French, the paper eventually argues that $w h \mathrm{SV}$ order in Dominican, and by extension, in other varieties of Caribbean Spanish, follows from ongoing morpho-syntactic changes that possibly result in the resetting of the null subject parameter: the development of a paradigm of weak subject pronouns, the concomitant establishment of a dedicated subject position, SpecTP, and the overall strong tendency towards SV order.
\end{abstract}

Keywords: interrogatives, word order, subject pronoun, paradigm, null-subject parameter, Caribbean Spanish, Dominican Spanish 


\section{Table of Contens}

\section{Introduction}

2. Previous investigations into $w h \mathrm{SV}$ order in varieties of Caribbean Spanish

3. Results from a large-scale quantitative analysis of colloquial Dominican Spanish

\author{
4. Previous approaches to $w h \mathrm{SV}$ \\ order in varieties of Caribbean \\ Spanish \\ 5. An alternative approach to $w h \mathrm{SV}$ \\ order in varieties of Caribbean \\ Spanish \\ 6. Conclusion \\ References
}

\section{Introduction}

In Spanish, a null-subject language with fairly free word order, (direct as well as indirect) interrogatives with a (fronted) simple (non-subject) argumental $w h$-expression generally stand out due to obligatory inversion of the (overt) subject and the verb. ${ }^{*}$ As illustrated in (1), such interrogatives have compulsory whVS order, as first established in Núñez Cedeño (1983) and Torrego (1984) (cf. also Hadlich 1971; Otheguy 1973; Solé \& Solé 1977).

a. ¿Qué quieres tú $?^{1}$

General Spanish

b. *¿Qué tú quieres?

General Spanish

'What do you want?' (Núñez Cedeño 1983, 51)

Varieties of Caribbean Spanish, principally Cuban, Dominican, and Puerto Rican, but also, to some extent, Columbian, Panamanian, and Venezuelan, have been particularly noted to deviate from this word order (inter alia Navarro Tomás 1929; 1948; Henríquez Ureña 1940; Davis 1971; Lipski 1977; 1990; 1994; RAE 2009b). ${ }^{2}$ In effect, since the late 1920s, it has been repeatedly reported that these varieties additionally allow for non-inversion of the subject and the verb, i.e. whSV order, as shown in (2). ${ }^{3}$

\footnotetext{
* $\quad$ For helpful comments on an earlier version of this paper, many thanks are due to the audience of the $1^{\text {st }}$ Spanish Dialects Meeting, Universidad Complutense de Madrid, 20-21 April 2017, as well as to Georg A. Kaiser and three anonymous reviewers. The usual disclaimers apply.

1 The occurrence of subject pronouns in General Spanish, a null-subject language, is usually restricted to contexts in which these elements are interpreted as either emphatic or contrastive, whence the putative markedness of (1a), as pointed out by an anonymous reviewer.

2 Deviations from $w h \mathrm{VS}$ order have likewise been reported for varieties from coastal Ecuador (Lipski 1990), River Plate region (Kany 1945; Zamora Munné \& Guitart 1988), Peru (Sessarego \& Gutiérrez-Rexach 2017), Mexico (Davis 1971; Cantero 1978 contra Lipski 1977), the U.S. (isleño Spanish of St. Bernard Parish, Louisiana) (Lipski 1990), the Canary Islands (inter alia Alvarez Nazario 1972; 1981; 1990; Lipski 1990; 1994; Lapesa 1992; Green 1997; RAE 2009b) as well as (Northern) Spain (Lapesa 1992; Lispki 1994; Green 1997). The exact extent of these deviations, both geographical and quantitative, is yet generally far from clear, pending further investigation.

3 As extensively discussed in Section 5, the positioning of subject pronouns in the varieties at issue directly relates to differences in their interpretation: postverbal subject pronouns such as in (2a) are interpreted as emphatic or contrastive, as in General Spanish (cf. also footnote 1);
} 
a. ¿Qué quieres tú?

b. ¿Qué tú quieres?

'What do you want?' (Núñez Cedeño 1983, 51)
Caribbean Spanish

Caribbean Spanish

While acknowledging the existence of such word order, ${ }^{4}$ these reports are far from concurring on both its frequency and the kind(s) of subject that can intervene between the whexpression and the verb. In particular, quantitative and qualitative claims range from an infrequent to a consistent use as well as from a strictly limited set of subject pronouns to the entire paradigm, possibly extending to full $\mathrm{D}$ (eterminer) $\mathrm{P}$ (hrase)s. Similarly, the approaches to $w h \mathrm{SV}$ order in varieties of Caribbean Spanish are manifold and, fundamentally, strongly divergent.

This paper sets out to reconsider the unsettled issues associated with whSV order in interrogatives in varieties of Caribbean Spanish by, essentially, carrying out a refined analysis of natural speech and putting forward an approach that takes into consideration other (morpho)syntactic hallmarks of these varieties, yet with a special focus on Dominican. Section 2 gathers the various claims put forward in the literature regarding the frequency of such word order as well as the specific nature of the preverbal subject and lists numerous reported examples. Section 3 presents the results from a refined large-scale quantitative analysis of a corpus of natural speech from colloquial Dominican Spanish that is contemporaneous to the detection of $w h \mathrm{SV}$ order and establishes that, in the late 1920s, such word order is possible only with the pronouns tú as well as usted and occurs in around 1 out of 2 and 4 cases, respectively. Section 4 discusses previous approaches to the phenomenon of $w h \mathrm{SV}$ order, showing that all of these face a number of problems. From this review as well as relevant analyses of data from medieval French that are akin to those reported for varieties of Caribbean, especially Dominican Spanish, Section 5 fundamentally argues that $w h \mathrm{SV}$ order is a direct result of current changes pertaining to the morpho-syntactic component, viz. the development of an additional paradigm of subject pronouns that are 'weak' in the sense of Cardinaletti \& Starke (1999), the concomitant establishment of SpecTP as an A-position, and the strong tendency towards SV order in all sentence types. Summarizing the preceding discussion, Section 6 eventually claims that these changes possibly bode a resetting of the null subject parameter.

with preverbal subject pronouns, as in ( $2 b)$, however, a non-emphatic, non-contrastive interpretation obtains, which conforms to that of a null subject in General Spanish.

WhSV order in interrogatives with a simple argumental wh-expression are commonly considered an innovation in varieties of Caribbean Spanish (inter alia Lantolf 1980a;b; Núñez Cedeño 1983; Burunat, Burunat \& Starčević 1987; Toribio 2000a;b; Bullock \& Toribio 2009). Note, however, that it is far from clear whether such word order is indeed a recent phenomenon, given that pertinent reports stem from no earlier than the end of the first third of the 20th century and, essentially, diachronic analyses are generally absent. To the best of my knowledge, there is but a single diachronic analysis of a fairly limited extent by Granda (1991), who, on the basis of an extract from a prose work of colloquial Dominican Spanish dating from the second half of the 18th century, reports no instances of whSV order with simple argumental whinterrogatives. Still, such word order is encountered in earlier stages of Peninsular Spanish (Lapesa 1992; RAE 2009b). In view of its general ungrammaticality in modern Peninsular Spanish, the existence of this word order in varieties of Caribbean Spanish has alternatively been conceived of as a relic emanating from Vulgar Latin, in which it likewise occurred (Lapesa 1992; RAE 2009b; cf. also Lipski 1990). Note, however, that the respective situations in Vulgar Latin and pre-modern Peninsular Spanish do not match completely, since, unlike the former, the latter exhibits $w h \mathrm{SV}$ order in indirect simple argumental $w h$-interrogatives only (Lapesa 1992). 


\section{Previous investigations into whSV order in varieties of Caribbean Spanish}

WhSV order in interrogatives in varieties of Caribbean Spanish has been on the research agenda ever since it had first been mentioned in the late 1920s. ${ }^{5}$ Despite the unanimous acknowledgement of the existence of such word order as well as the extensive period of time that has since elapsed, researchers still strongly disagree on both its frequency and the kind(s) of intervening subject.

Regarding the latter issue, specific information on the kind(s) of preverbal subject is usually missing in the vast literature addressing whSV order. Comparatively few contributions only provide details as to what kind(s) of subject can occur between the wh-expression and the verb, and several of these fail to be specific about which varieties of Caribbean Spanish are affected. Glossing over any putative variety-specific differences, it appears that the preverbal occurrence of the non-deferential specific second person singular subject pronoun, tú, is uncontroversial (cf. (3)).

a. ¿Qué tú dices?

Cuban/Dominican/Puerto Rican Spanish 'What are you saying?' (inter alios Navarro Tomás 1929, 133; Patín Maceo 1940, 162; Padrón 1948, 468)

b. ¿Cómo tú te llamas?

Cuban/Dominican/Puerto Rican Spanish 'What is your name?' (inter alios Patín Maceo 1940, 50; Padrón 1948, 468; Lipski 1977, 61)

As to the possibility of the preverbal occurrence of subject elements other than tú there is yet considerable controversy. While Davis (1971) as well as the impressionistic data given by numerous researchers, who exclusively provide examples, rather than relevant details, defy such a possibility, a fair number of researchers claim that whSV order is likewise possible with the deferential second person singular and plural subject pronouns, usted (cf. (4)) and ustedes (cf. (5)) (inter alia Navarro Tomás 1948; Quirk 1972; Lantolf 1980a; Suñer \& Lizardi 1995; Ortiz López 2009b). ${ }^{6}$

a. ¿Qué usted quiere?

Puerto Rican Spanish 'What do you want?' (Navarro Tomás 1948, 132; Alvarez Nazario 1990, 183)

b. ¿Dónde usted se va a sentá?

'Where are you going to sit?' (Green 1997, 227)

Dominican Spanish

$5 \quad$ With the notable exceptions of López Morales (1992), Fontana (1994), Suñer (1994), and Dumitrescu (2016), the literature remains silent on whether pertinent claims hold for indirect (argumental) $w h$-interrogatives as well. From the vast majority of the examples adduced, one is led to conclude that claims basically apply to direct $w h$-interrogatives. This evidently clashes with the null hypothesis that, as in General Spanish, the same word order obtains in both direct and indirect interrogatives in varieties of Caribbean Spanish. That $w h \mathrm{SV}$ order is indeed possible in indirect $w h$-interrogatives in these varieties can, in addition to López Morales, Fontana, Suñer, and Dumitrescu's notes, be inferred from relevant examples provided by a small number of researchers without further discussion (Me preguntó cómo yo me llamaba 'He asked me what my name was' (Gutiérrez Araus 1987, 1005), Me dijo que cuántas capas yo llevaba debajo 'She asked me how many layers I was wearing underneath' (Suñer \& Lizardi 1995, 193)). For reasons of consistency, this section lists only direct $w h$-interrogatives.

6 In the literature, examples illustrating the preverbal occurrence of usted and ustedes in Cuban Spanish are missing. 
a. ¿Qué ustedes buscan por aquí?

'What are you looking for here?' (Gili Gaya 1966, 53)

b. ¿A quién ustedes quiere ver?

'Who do you want to see?' (Jiménez Sabater 1977, 14)

Puerto Rican Spanish

Dominican Spanish

Several researchers furthermore contend that the first person singular subject pronoun, yo, can also show up in whSV order (cf. (6)) (inter alia Navarro Tomás 1948; Bergen 1976; Alvarez Nazario 1981; 1990; Green 1997; Ordóñez \& Olarrea 2006). ${ }^{7}$

a. ¿Qué yo hice?

'What did I do?' (Brown \& Rivas 2011, 25)

b. ¿Qué yo les mando a esos muchachos?

'What do I send these guys?' (Toribio 1993, 168)
Puerto Rican Spanish

Dominican Spanish

Some researchers additionally state that the first person plural subject pronoun, nosotros/nosotras, may likewise intervene (cf. (7)) (Lantolf 1980a; Suñer \& Lizardi 1995; Ordóñez \& Olarrea 2006; Ortiz López 2009b), ${ }^{8}$ much like the third person singular subject pronouns, él and ella (cf. (8)) (Lipski 1977; Lantolf 1980a; Olarrea 2006; Ortiz López 2009b; 2016). ${ }^{9}$

¿Qué nosotras haríamos si [...]?

'What would we do, if ...?' (Suñer \& Lizardi 1995, 194)

Puerto Rican Spanish

a. ¿Qué él va a hacer allá?

'What is he going to do there?' (Suñer \& Lizardi 1995, 193)

b. ¿Dónde ella vive?

'Where does she live?' (Ortiz López 2009b, 96; 2016, 319)

Puerto Rican Spanish

Dominican Spanish

According to a minority of researchers, the kind of subject occurring in $w h \mathrm{SV}$ order also comprises the third person plural subject pronouns, ellos and ellas (cf. (9)) (Lipski 1977; Olarrea 2006; Cabrera-Puche 2008; Ortiz López 2009b). ${ }^{10}$

a. ¿Qué ellos trajeron a la fiesta?

Caribbean Spanish

'What did they bring to the party?' (Ordóñez \& Olarrea 2001, 233; 2006, 68)

b. ¿Dónde ellos están?

Caribbean Spanish

'Where are they?' (Núñez Cedeño 1983, 37)

Based on the claims in the literature, the scale in (10) can be established, which displays in schematic form and descending order the rates of acceptance of subject pronouns in

$7 \quad$ Examples with yo in Cuban Spanish are absent in the literature.

8 The literature does not provide examples for intervening nosotras in varieties of Caribbean Spanish other than Puerto Rican and, more generally so, for intervening nosotros.

9 Examples with preverbal él in Cuban Spanish are also absent in the literature, along with those showing ella in preverbal position in varieties of Caribbean Spanish other than Dominican.

10

Unlike in the case of the other subject pronouns, the literature does not provide examples with either ellos or ellas that are explicitly classified as belonging to a specific variety of Caribbean Spanish. Rather than refraining from illustrating at least preverbal ellos (examples of ellas in preverbal position are entirely absent), examples argued to hold for 'Caribbean Spanish' are provided. 
interrogatives with $w h \mathrm{SV}$ order in varieties of Caribbean Spanish, both in general and in specific varieties (notably Dominican and Puerto Rican).

tú > usted, ustedes > yo > nosotros/nosotras, éllella > ellos/ellas

Fundamentally, not only is the state of affairs regarding the kind of subject pronoun allowed to intervene between the wh-expression and the verb highly controversial, but also the situation concerning full DP subjects. In effect, only few researchers address this matter, and those who do so express viewpoints that are mutually exclusive. While according to some researchers, $w h \mathrm{SV}$ order is impossible with full DP subjects in any variety of Caribbean Spanish (inter alia Padrón 1948; Lipski 1977; Núñez Cedeño 1983; Brown \& Rivas 2011; Ordóñez 2016), other researchers underscore the possibility of the preverbal occurrence of this kind of subject, particularly in Dominican and Puerto Rican Spanish, and/or give examples (cf. (11)) (inter alia Lantolf 1980a;b; Toribio 1993; 2000a;b; Cabrera-Puche 2008; Ortiz López 2009a;b; 2016; Martínez-Sanz 2011).

a. ¿Qué Juan tiene?

'What does Juan have?' (Lantolf 1980b, 215)

b. Papi, ¿qué ese letrero dice?

'Daddy, what does this sign say?' (Toribio 2000a, 630; 2000b, 322)

Puerto Rican Spanish

c. ¿Cuánto un médico consume en un mes?

'How much does a doctor spend in a month?' (Toribio 1993, 168)

d. ¿Dónde Astrid vive?

'Where does Astrid live?' (Ortiz López 2016, 319)

e. ¿Por dónde la carretera queda?

'Where about is the highway located?' (Suñer \& Lizardi 1995, 195)

f. ¿A quién en este momento Juan está entrevistando?

'Who is Juan presently interviewing?' (Suñer \& Lizardi 1995, 201)

Caribbean Spanish

Puerto Rican Spanish

Puerto Rican Spanish

From the incorporation of the claims from the literature regarding full DP subjects into the scale of acceptance of subject pronouns in interrogatives with whSV order in (10) above, the exhaustive acceptability scale in (12) results, that appears to hold in varieties of Caribbean Spanish in general and Dominican and Puerto Rican in particular.

tú > usted, ustedes > yo > nosotros/nosotras, él/ella > ellos/ellas > full DP subject

Turning now to the issue of the frequency of $w h \mathrm{SV}$ order in varieties of Caribbean Spanish, pertinent claims in the literature are few and far between and usually provide little, if any information, from which the frequency of a particular preverbal subject element in a given variety of Caribbean Spanish can be deduced.

From the quantitative claims found in the literature, the overall picture in Table (1) ensues, which in fact closely matches those relating to specific varieties of Caribbean Spanish (Cuban, Dominican as well as Puerto Rican).

As it stands, the literature is far from concurring on the frequency of whSV order in varieties of Caribbean Spanish. In effect, quantitative claims at times diverge considerably, attesting to an altogether wide range of frequencies of preverbal subjects. Abstracting away from the shortcomings commonly inherent to these quantitative claims (cf. Section 3) as well as from their at times strong contradictoriness, it seems that, in varieties of Caribbean Spanish, $w h \mathrm{SV}$ order is a regular phenomenon. Yet, this is apparently only the case with pronominal 
subjects, while, with non-pronominal ones, whVS order predominates, at least according to those researchers that concur that such a kind of subject can occur preverbally.

\begin{tabular}{|l|c|c|c|c|}
\hline & infrequent & frequent & highly frequent & consistent \\
\hline $\begin{array}{l}\text { subject (not further } \\
\text { specified) }\end{array}$ & 1 & 12 & 14 & 1 \\
\hline subject pronoun & 1 & 5 & 3 & 1 \\
\hline full DP subject & 2 & 1 & - & - \\
\hline total & 4 & 18 & 17 & 2 \\
\hline
\end{tabular}

Table (1): Frequencies of $w h \mathrm{SV}$ order in varieties of Caribbean Spanish as reported in a multitude of pieces of research ${ }^{11}$

Even though some light has been shed on the frequency of $w h \mathrm{SV}$ order and the specific nature of the subject intervening between the $w h$-expression and the verb in interrogatives in varieties of Caribbean Spanish, these issues are still far from clear, pending further investigation.

\section{Results from a large-scale quantitative analysis of colloquial Dominican Spanish}

The discussion in the previous section has shown that, despite their being on the research agenda for almost a hundred years, researchers are far from agreeing on the two central issues relating to $w h \mathrm{SV}$ order in interrogatives in varieties of Caribbean Spanish: the frequency of such word order as well as the specific nature of the preverbal subject. In effect, quantitative claims in the literature range from an infrequent to a consistent use of $w h \mathrm{SV}$ order as well as from an exclusive subset of subject pronouns to their entire paradigm, possibly extending to full DPs.

According to a number of researchers, such strong disagreement is not indicative of variation among or within varieties of Caribbean Spanish, but rather due to two major shortcomings affecting the literature to varying degrees. Specifically, it has been observed that the examples provided to illustrate $w h \mathrm{SV}$ order are discrepant, since many of these actually contain wh-expressions that fail to be simple and/or argumental and, thus, allow for noninversion of the subject and the verb in Spanish (Ordóñez \& Olarrea 2001; 2006). Moreover, it has been pointed out that pertinent claims are usually based on personal impression, anecdote as well as questionnaires distributed to native speakers, rather than on unequivocal empirical evidence based on large-scale quantitative analyses of natural speech (Heap 1990; Suñer \& Lizardi 1995; D'Introno 2000; Brown \& Rivas 2011). Arguably, the general absence of the latter relates to the difficulties associated with a systematic study of $w h \mathrm{SV}$ order in varieties of Caribbean Spanish, viz. its principal occurrence in non-standard or colloquial speech (Lipski 1977), the availability of null subjects (cf. farther below and Section 4), and, more generally, the rare occurrence of interrogatives in natural speech (Lipski 1977; D'Introno 2000; MartínezSanz 2011; Peralta Céspedes 2017).

11 The digits given in the table each relate to the respective number of pieces of research, that comprise the following bulk of work: Patín Maceo (1940); Kany (1945); Henríquez Ureña (1948); Padrón (1948; 1949a;b); Gili Gaya (1966); Davis (1971); Pérez Sala (1971; 1973); Quirk (1972); Jiménez Sabater (1977; 1999); Jorge Morel (1978); Lantolf (1980a;b); Megenney (1985); Buesa Oliver (1986); Gutiérrez Araus (1987); Green (1988); Alvarez Nazario (1990); Liceras (1994); Suñer (1994); Suñer \& Lizardi (1995); Lunn (2002); Alba (2004); Ticio (2004); Ordóñez \& Olarrea (2006); Cabrera-Puche (2008); Camacho (2008); Gutiérrez-Bravo (2008); Ortiz López (2009a); Brown \& Rivas (2011); Butt \& Benjamin (2011); Martínez-Sanz (2011); Rivas \& Brown (2011); Peralta Céspedes (2017). 
Although few in number, large-scale quantitative analyses tackling whSV order in specific varieties of Caribbean Spanish (Dominican and Puerto Rican) do exist. To the best of my knowledge, there are four such analyses, viz. Suñer \& Lizardi (1995), Cabrera-Puche (2008), Martínez-Sanz (2011), and Rivas \& Brown (2011). Yet, all of these suffer from a number of flaws that considerably reduce the gain in further insight into the issues under investigation. These flaws primarily relate to either the failure to indicate which subject pronouns can occur in preverbal position as well as what the respective frequencies of preverbal subject elements are - this pertains to Suñer \& Lizardi (1995) and Cabrera-Puche's (2008) analyses - or the disregard of both a subset of subject pronouns and the argumental nature of wh-expressions, as is the case with Martínez-Sanz (2011) and Rivas \& Brown's (2011) analyses.

In an attempt to partly fill the persisting lacuna of refined large-scale quantitative analyses of natural colloquial speech from varieties of Caribbean Spanish that, essentially, take into consideration the complexity as well as the argumental nature of $w h$-expressions, in what follows I present results from an analysis based on a corpus of colloquial Dominican Spanish spoken almost a century ago. Fundamentally, this corpus allows to determine the relevant state of affairs at the very time when whSV order was first taken notice of in the literature, and to compare it with today's situation.

The corpus in question comprises a large number of stories from oral tradition that were collected by Manuel J. Andrade in the summer of 1927 and published in 1930 as the major part of his monograph entitled Folklore from the Dominican Republic. Specifically, the corpus encompasses 304 tales stretching over a total of 325 pages.

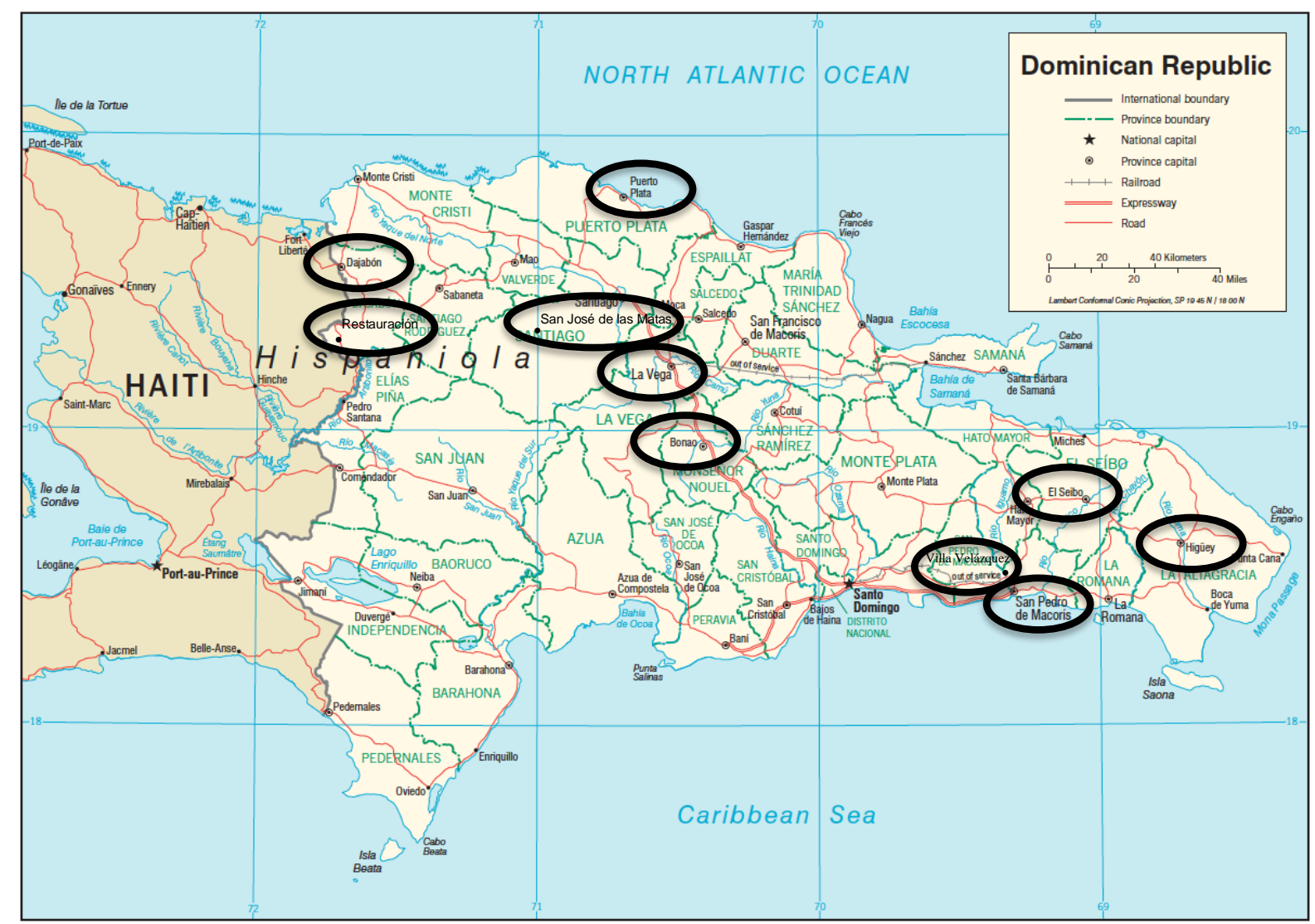

Figure (1): Location of the municipalities selected by Andrade (1930) ${ }^{12}$

The map underlying Figure (1) was downloaded on 7 March 2017 from the online map collection of the Perry-Castañeda Library of the University of Texas at Austin, using the following link: http://www.lib.utexas.edu/maps/americas/dominican_republic_pol-2004.pdf. 
As Andrade was eager to capture natural colloquial speech free from normative pressures as well as prescriptive use of language, he primarily consulted informants that were illiterate, belonged to the occupational class of unskilled laborers, and lived in rural districts some of which neighbored larger municipalities. Andrade $(1930,8)$ himself qualifies his informants as "the peasants and the uneducated city folk". In total, Andrade collected stories from 78 informants ranging from 15 to 80 years of age and living in areas surrounding the cities and villages illustrated in Figure (1): Restauración (west), Dajabón (northwest), Monte Cristi (northwest), Puerto Plata (north), San José de las Matas (center), La Vega (center), Bonao (center), Seibo (east), Higuiey (east), San Pedro de Macorís (southeast), and Villa Velázquez (southeast).

The informants usually first recited their tales and then dictated them to Andrade, who wrote them down by employing a mixture of phonetic rendering and Spanish orthography. Occasionally, informants dictated stories to young(er) relatives that could write or wrote them down themselves when they were literate to some extent. Such writings met with great caution on the part of Andrade $(1930,24)$, who actually made sure that these "were reproduced from oral tradition" and, for reasons of better intelligibility, corrected their orthography.

Having detailed the methodology underlying the corpus presently made use of, I now turn to the two central issues under investigation regarding direct ${ }^{13}$ interrogatives with a simple argumental $w h$-expression, viz. the frequency of $w h \mathrm{SV}$ order and the specific nature of the preverbal subject.

A total of 344 direct interrogatives produced by 46 informants are encountered. Of these, 138 are of the yes/no kind and 206 of the wh kind (cf. Table (2)), provided by 38 informants each.

\begin{tabular}{|l|c|}
\hline & $\#$ \\
\hline yes/no & 138 \\
\hline wh & 206 \\
\hline total & 344 \\
\hline
\end{tabular}

Table (2): Kinds of direct interrogatives

Regarding $w h$-interrogatives, whose $w h$-expressions are in fact consistently non-subject in nature and which all constitute information-requesting questions, ${ }^{14} 29$ contain a cleft, viz. "the formula QU-word -SER - (lo) - que 'WH-word - to-be - ('lo') -that"” (Suñer 1986, 197). Of the remainder, 89 have a null subject and 88 an overt subject, as Table (3) illustrates.

\begin{tabular}{|l|c|}
\hline & $\#$ \\
\hline cleft & 29 \\
\hline non-cleft, null subject & 89 \\
\hline non-cleft, overt subject & 88 \\
\hline total & 206 \\
\hline
\end{tabular}

Table (3): Kinds of direct $w h$-interrogatives

As shown in Table (4), of the $88 w h$-interrogatives with an overt subject, 19, expressed by 16 informants, have a non-argumental $w h$-expression and, essentially, 69 , produced by 30

13 The present restriction is a regrettable, yet necessary step. The state of affairs in indirect interrogatives is thus pending further investigation.

14 In effect, an answer by another character is provided subsequently to each of the established wh-interrogatives. 
informants, have an argumental $w$-expression that is actually invariably simple in nature. ${ }^{15}$

\begin{tabular}{|l|c|}
\hline & $\#$ \\
\hline non-argumental & 19 \\
\hline argumental & 69 \\
\hline total & 88 \\
\hline
\end{tabular}

Table (4): Argumental status of $w h$-expressions in direct non-cleft $w h$-interrogatives with an overt subject

I start by investigating non-argumental wh-interrogatives, which allow for noninversion of the subject and the verb in Spanish to varying degrees. ${ }^{16} \mathrm{WhSV}$ order and $w h \mathrm{VS}$ order were each employed by 8 informants, the latter order showing a slight predominance (cf. Table (5)).

\begin{tabular}{|l|c|c|}
\hline & $\#$ & \% \\
\hline preverbal & 8 & 42.1 \\
\hline postverbal & 11 & 57.9 \\
\hline total & 19 & 100 \\
\hline
\end{tabular}

Table (5): Positioning of the overt subject in direct non-cleft non-argumental $w h$ interrogatives

A closer look at these interrogatives reveals that the kind of subject occurring with $w h \mathrm{SV}$ order is strictly limited. In effect, only a small subset of subject pronouns shows up with this word order, viz. the non-deferential specific as well as the deferential second person singular subject pronouns, tú and usted. Examples are given in (13) and (14).

a. ¿Poi qué tú yora?

'Why are you crying?' (LuJoSu, illiterate, peasant, 30, San José de las Matas, 80) ${ }^{17}$

b. Toribito, ¿dónde tu conseguite to ete dinero?

'Toribito, where did you get all this money from?' (CaSá, illiterate, 20, Seibo, 42)

(14) a. Mire, amigo, poi qué uté me pisó?

'Well, friend, why did you hit me?' (LuCoMo, illiterate, peasant, 17, Monte Cristi, 294)

b. ¿Dónde uté consiguió eto?

'Where did you get this from?' (LuCaAr, literate, 16, Higüey, 78)

15 In the present paper, I make use of 'simple' to refer to argumental $w h$-expressions that do not comprise more than two words in General Spanish orthography. Therefore, I exclude heavy as well as complex argumental $w h$-expressions that, similar to non-argumental ones, allow for noninversion of the subject and the verb in Spanish to varying degrees (inter alia Torrego 1984; Ordóñez \& Treviño 1999; Zubizarreta 1999; Ordóñez \& Olarrea 2001; 2006; Ordóñez 2016). Note that, in the vast majority of established argumental $w h$-interrogatives, the $w h$-expression consists of a single word.

16 Cf. footnote 15.

17 All corpus examples are appended by information relating to the informants that produced the sentences contained in these examples. Unless Andrade does not provide relevant details, the pieces of information given are as follows and in this order: name (abbreviated; for full name cf. Andrade), literacy, job, age, municipality, page number in Andrade's monograph. 
In contrast, whVS order comprises not only a larger subset of subject pronouns, extending, in addition to tú (cf. (15a)) and usted (cf. (15b)), to the first person singular subject pronoun, yo (cf. (15c)), but also the demonstrative pronoun eso (cf. (15d)) and (singular) full DP subjects (cf. (15e)).

(15) a. Helmano, ¿para qué ere tú resusitadol?

'Brother, what are you a resuscitator for?' (FrDe, illiterate, cab-driver, 40, San Pedro de Macorís, 92)

b. ¿Por qué se robó uté eso chivo?

'Why did you steal these kids?' (JuAm, literate, 67, La Vega, 312)

c. ¿Con qué le pago yo a eta pobre viuda?

'How shall I pay the poor widow?' (JuCa, illiterate, 18, Seibo, 305)

d. ¿pa pué fué eso?

'what was this for?' (BiFa, illiterate, bootblack, 17, San Pedro de Macorís, 167)

e. ¿Y por qué yora la prinsesita tan bonita?

'And why does the princess that is so beautiful cry?' (CoRu, literate, dish-washer, 18, Seibo, 298)

When exclusively looking at interrogatives with tú and usted, the sole subject elements that show up pre- as well as postverbally, the picture turns out to be quite different from the comprehensive one (cf. Table (5) above): with tú, whSV order is predominant (cf. Table (6)), while with usted, no preference for a specific word order can be determined (cf. Table (7)).

\begin{tabular}{|l|c|c|}
\hline & $\#$ & \% \\
\hline preverbal & 5 & 71.4 \\
\hline postverbal & 2 & 28.6 \\
\hline total & 7 & 100 \\
\hline
\end{tabular}

Table (6): Positioning of tú in direct non-cleft non-argumental $w h$-interrogatives

\begin{tabular}{|l|c|c|}
\hline & $\#$ & $\%$ \\
\hline preverbal & 3 & 50 \\
\hline postverbal & 3 & 50 \\
\hline total & 6 & 100 \\
\hline
\end{tabular}

Table (7): Positioning of usted in direct non-cleft non-argumental wh-interrogatives

It is interesting to note that, as shown in Table (8), none of the informants that produced $w h \mathrm{SV}$ order provided a single instance of $w h \mathrm{VS}$ order and, conversely, none of the informants expressing $w h \mathrm{VS}$ order made use of $w h \mathrm{SV}$ order.

This does not seem to result from diatopic variation, since, as Table (8) illustrates, several of the municipalities with informants solely producing $w h \mathrm{SV}$ order are likewise home to those exclusively using whVS order (Higüey, La Vega, San Pedro de Macorís). Age per se does not appear to play a crucial role either, given that the majority of the informants providing one of these word orders belong to the same age groups (cf. Table (8)). Yet, it is quite noteworthy that, while none of the informants that expressed whSV order was older than 30 years, ${ }^{18}$ those employing whVS order were generally considerably older: 3 out of the 4 informants that made use of $w h \mathrm{VS}$ order were aged 40,67 , and 80, respectively. 


\begin{tabular}{|l|l|c|c|c|}
\hline informant & municipality & age & whSV & whVS \\
\hline JuAr & Higüey & 80 & $\boldsymbol{x}$ & $\checkmark$ \\
\hline LuCaAr & Higüey & 16 & $\checkmark$ & x \\
\hline JuAm & La Vega & 67 & $\mathbf{x}$ & $\checkmark$ \\
\hline JVSo & La Vega & 18 & $\checkmark$ & x \\
\hline LuCoMo & Monte Cristi & 17 & $\checkmark$ & $\mathbf{x}$ \\
\hline JoAb & San José de las Matas & 16 & $\checkmark$ & $\mathbf{x}$ \\
\hline LuJoSu & San José de las Matas & 30 & $\checkmark$ & x \\
\hline FrDe & San Pedro de Macorís & 40 & $\mathbf{x}$ & $\checkmark$ \\
\hline BiFa & San Pedro de Macorís & 17 & $\mathbf{x}$ & $\checkmark$ \\
\hline JoJuRi & San Pedro de Macorís & - & $\checkmark$ & $\mathbf{x}$ \\
\hline FéAn & Seibo & 30 & $\checkmark$ & $\mathbf{x}$ \\
\hline CaSá & Seibo & 20 & $\checkmark$ & $\mathbf{x}$ \\
\hline
\end{tabular}

Table (8): Informants employing tú and/or usted in direct non-cleft non-argumental $w h$ interrogatives

Turning now to (simple) argumental $w h$-interrogatives, the picture proves to be somewhat similar to that established for non-argumental ones. 11 informants produced $w h \mathrm{SV}$ order, $19 w h \mathrm{VS}$ order. The overall number of interrogatives with an argumental $w h$-expression discloses a strong predominance of postverbal subjects, as Table (9) illustrates.

\begin{tabular}{|l|c|c|}
\hline & $\#$ & \% \\
\hline preverbal & 20 & 29 \\
\hline postverbal & 49 & 71 \\
\hline total & 69 & 100 \\
\hline
\end{tabular}

Table (9): Positioning of the overt subject in direct non-cleft argumental $w h$ interrogatives

A closer look reveals again a strict limitation of the kind of subject showing up in $w h \mathrm{SV}$ order, viz. tú and usted, the non-deferential specific and the deferential second person singular subject pronoun, respectively. Examples are provided in (16) and (17).

(16) ¿. ¿Qué tú buca po aquí?

'What are you looking for here?' (JoAnAr, illiterate, peasant, 15, San Pedro de Macorís, 103) ${ }^{19}$

b. ¿Cuánto talego tú me da y te alimo?

'How many sacks do you give me, if I file you?' (BiFa, illiterate, bootblack, 17, San Pedro de Macorís, 329) ${ }^{20}$

(17) a. ¿Cómo uté se ñama?

'What is your name?' (RaPe, literate, peasant, 15, La Vega, 185)

b. ¿A dónde uté va, mai vieja?

'Where are you going, my dear old one?' (AnAr, illiterate, peasant, 16, Restauración, 289)

19 The interrogative in (16a) was also produced by the following informants (and at times more than once): BiFa, illiterate, bootblack, 17, San Pedro de Macorís, 160, 273, 274; GuSá, bootblack, 19, San Pedro de Macorís, 55; CaSá, illiterate, 20, Seibo, 115. p.329). 
With $w h$ VS order, by contrast, the set of pronominal subjects encompasses, besides tú (cf. (18a)) and usted (cf. (18b)), yo (cf. (18c)) as well as ustedes (cf. (18d)), the first person singular and the deferential second person plural subject pronoun, respectively. Furthermore, full DP subjects, both singular (cf. (18e)) and plural (cf. (18f)), are found with such word order.

(18) a. ¿Qué buca tú po aquí, Juan?

'What are you looking for here, John?' (BiFa, illiterate, bootblack, 17, San Pedro de Macorís, 159)

b. Compái Pedro, ¿qué anda uté hasiendo aquí?

'Pedro, my friend, what are doing here?' (JVSo, 18, La Vega, 50)

c. ¿Qué le digo yo?

'What do I tell him?' (FéAn, illiterate, peasant, 30, Seibo, 268-269)

d. Mi suiso, ¿qué bucan utede po-r-aquí?

'My darlings, what are you looking for here?' (FrDe, illiterate, cab-driver, 40, San Pedro de Macorís, 92)

e. ¿Qué hiso Juan Bobo?

'What did Juan Bobo do?' (GuSá, bootblack, 19, San Pedro de Macorís, 54)

f. ¿Cómo e’tán mis hijito?

'How are my children doing?' (CoRu, literate, dish-washer, 18, Seibo, 122)

When exclusively taking into consideration those interrogatives that contain subject elements that are attested in pre- as well as postverbal position, i.e. those with tú and usted, the picture turns out to be somewhat different from that above: whereas the results concerning usted are actually in line with the latter, since this subject pronoun occurs preferably in postverbal position (cf. Table (11)), preverbal and postverbal positioning fairly balance out one another regarding tú (cf. Table (10)), for which, thus, no dedicated preference for a specific word order can be established.

\begin{tabular}{|l|c|c|}
\hline & $\#$ & \% \\
\hline preverbal & 17 & 51.5 \\
\hline postverbal & 16 & 48.5 \\
\hline total & 33 & 100 \\
\hline
\end{tabular}

Table (10): Positioning of $t u ́$ in direct non-cleft argumental $w h$-interrogatives

\begin{tabular}{|l|c|c|}
\hline & $\#$ & \% \\
\hline preverbal & 3 & 27.3 \\
\hline postverbal & 8 & 72.7 \\
\hline total & 11 & 100 \\
\hline
\end{tabular}

Table (11): Positioning of usted in direct non-cleft argumental $w h$-interrogatives

Unlike in the case of non-argumental $w h$-interrogatives, a fair number of informants (a total of 5) produced $w h \mathrm{SV}$ order along with $w h \mathrm{VS}$ order with argumental $w h$-interrogatives comprising subject elements attested both pre- as well as postverbally (cf. Table (12)).

\begin{tabular}{|l|l|c|c|c|}
\hline informant & municipality & age & whSV & whVS \\
\hline SóMe & Bonao & 18 & $\boldsymbol{x}$ & $\checkmark$ \\
\hline $\mathrm{JuAr}$ & Higüey & 80 & $\boldsymbol{x}$ & $\checkmark$ \\
\hline $\mathrm{LuCaAr}$ & Higüey & 16 & $\checkmark$ & $\boldsymbol{x}$ \\
\hline JuAnMe & La Vega & 60 & $\boldsymbol{x}$ & $\checkmark$ \\
\hline
\end{tabular}




\begin{tabular}{|l|l|c|c|c|}
\hline RaPe & La Vega & 15 & $\checkmark$ & x \\
\hline JVSo & La Vega & 18 & x & $\checkmark$ \\
\hline LuCoMo & Monte Cristi & 17 & x & $\checkmark$ \\
\hline JeMaMo & Monte Cristi & 23 & x & $\checkmark$ \\
\hline MaPo & Monte Cristi & 26 & $\checkmark$ & x \\
\hline AnAr & Restauración & 16 & $\checkmark$ & $\checkmark$ \\
\hline LuJoSu & San José de las Matas & 30 & $\checkmark$ & x \\
\hline JoAnAr & San Pedro de Macorís & 15 & $\checkmark$ & x \\
\hline FrDe & San Pedro de Macorís & 40 & $\checkmark$ & $\checkmark$ \\
\hline BiFa & San Pedro de Macorís & 17 & $\checkmark$ & $\checkmark$ \\
\hline GuSá & San Pedro de Macorís & 19 & $\checkmark$ & x \\
\hline AnCa & Seibo & 18 & x & $\checkmark$ \\
\hline JuCa & Seibo & 18 & $\checkmark$ & $\checkmark$ \\
\hline CaSá & Seibo & 21 & $\mathbf{x}$ & $\checkmark$ \\
\hline GuMo & Seibo & $\checkmark$ & $\checkmark$ \\
\hline
\end{tabular}

Table (12): Informants employing tú and/or usted in direct non-cleft argumental whinterrogatives

A particularly telling example is given in (19), which displays the rendering of an argumental $w h$-interrogative in the same tale in terms of either word order. ${ }^{21}$

¿Qué quiere tú? [...] ¿Qué tú quiere?

'What do you want? What do you want?' (JuCa, illiterate, 18, Seibo, 62-63)

Still, there are several informants making exclusive use of either $w h \mathrm{SV}$ order (6 in total) or whVS order (a total of 8). As shown in Table (12) above, however, the municipalities established for the informants making use of whSV order generally match those of the informants expressing whVS order (Higüey, La Vega, Monte Cristi, San Pedro de Macorís, Seibo). This finding, which strongly argues against diatopic variation, is reminiscent of the one regarding non-argumental $w h$-interrogatives, much like the observations that most of the pertinent informants form part of the same age groups and that, unlike $w h \mathrm{VS}$ order, $w h \mathrm{SV}$ order was not employed by middle aged or elderly informants (cf. again Table (12)).

A wide variety of word order combinations is attested - ranging from consistent inversion to consistent non-inversion - regarding those informants that employ both nonargumental and argumental $w h$-interrogatives with subject elements occurring pre- as well as postverbally, i.e. tú and usted (cf. Table (13)). Fundamentally, the possibility of non-inversion in argumental $w h$-interrogatives does not seem to necessarily correlate with such possibility in non-argumental $w h$-interrogatives and vice versa. It is also noteworthy that, unlike all other informants, who make use of $w h \mathrm{SV}$ order to different degrees, the one informant producing exclusively $w h \mathrm{VS}$ order is elderly.

\begin{tabular}{|l|l|c|c|c|c|c|}
\hline \multirow{2}{*}{ informant } & \multirow{2}{*}{ municipality } & \multirow{2}{*}{ age } & \multicolumn{2}{|c|}{ argumental } & \multicolumn{2}{c|}{ non-argumental } \\
\cline { 4 - 7 } & & & $w h S V$ & $w h V S$ & $w h S V$ & $w h$ VS \\
\hline $\mathrm{JuAr}$ & Higüey & 80 & $\mathbf{x}$ & $\checkmark$ & $\mathbf{x}$ & $\checkmark$ \\
\hline
\end{tabular}

As (19) straightforwardly illustrates and is extensively discussed in Section 5, verb type does not have an impact on the positioning of the subject pronoun regarding the verb; rather, as pointed out in footnote 3 and explained in Section 5, the respective positioning ties in with interpretational differences. 


\begin{tabular}{|l|l|c|c|c|c|c|}
\hline LuCaAr & Higüey & 16 & $\checkmark$ & x & $\checkmark$ & x \\
\hline JVSo & La Vega & 18 & x & $\checkmark$ & $\checkmark$ & x \\
\hline LuCoMo & Monte Cristi & 17 & $\mathbf{x}$ & $\checkmark$ & $\checkmark$ & x \\
\hline LuJoSu & San José de las Matas & 30 & $\checkmark$ & $\mathbf{x}$ & $\checkmark$ & x \\
\hline FrDe & San Pedro de Macorís & 40 & $\checkmark$ & $\checkmark$ & $\mathbf{x}$ & $\checkmark$ \\
\hline BiFa & San Pedro de Macorís & 17 & $\checkmark$ & $\checkmark$ & $\mathbf{x}$ & $\checkmark$ \\
\hline CaSá & Seibo & 20 & $\checkmark$ & $\checkmark$ & $\checkmark$ & x \\
\hline
\end{tabular}

Table (13): Informants employing tú and/or usted in direct non-cleft non-argumental as well as argumental $w h$-interrogatives

From the results presented in this section one may thus conclude that non-inversion of the subject and the verb in direct simple argumental $w h$-interrogatives was a fairly restricted word order young adult speakers of colloquial Dominican Spanish in the late 1920s produced with the pronouns tú and usted in around 1 out of 2 and 4 cases, respectively. The very same word order restrictions held for direct non-argumental $w$ h-interrogatives that were in fact more frequently expressed with $w h \mathrm{SV}$ order, viz. in around 2 out of 3 (tú) as well as 1 out of 2 (usted) cases. $^{22}$

When comparing these results with the few claims in the literature that pertain exclusively to Dominican Spanish, it appears that, in the course of the 20th and 21st centuries, restrictions on non-inverted word order in $w h$-interrogatives have become considerably relaxed, if not entirely lifted, and the use of such word order has gained vital momentum. ${ }^{23}$ In effect, pertinent claims indicate that $w h \mathrm{SV}$ order is, at least since the late 1970s, also possible with yo and ustedes (Jiménez Sabater 1977; 1999; Toribio 1993; 2000b; Green 1997; Bullock \& Toribio 2009) and, ever since the end of the 20th century, additionally with él / ella (Jiménez Sabater 1999; Lunn 2002). According to the most recent claim (Ortiz López 2009b), the entire set of subject pronouns can nowadays occur with $w h \mathrm{SV}$ order. Furthermore, at least since the early 1990s, full DP subjects have become possible with such word order (Toribio 1993; 2000b; Cabrera-Puche 2008; Ortiz López 2009b). Regarding the frequency of its use, whSV order was apparently increasingly employed (Henríquez Ureña 1948) or even strongly preferred (Patín Maceo 1940) in the 1940s and strongly favored in the late 1970s (Jiménez Sabater 1977; Jorge Morel 1978). From the turn of the millennium onward, whSV order has been used regularly (Jiménez Sabater 1999; Alba 2004; Cabrera-Puche 2008), if not exclusively (Lunn 2002; Camacho 2008).

Closing this section, I suggest, in accordance with various researchers (cf. footnote 4), that $w h \mathrm{SV}$ order in interrogatives constitutes an innovation in colloquial Dominican Spanish and assume in this regard that the origins of such word order in this variety date back to the late 19th century. ${ }^{24}$

22 That the second person singular pronouns were evidently the first subject elements to show up between the wh-expression and the verb (cf. also Section 2 as well as Lipski 1977; Heap 1990), hereby leading the way for other pronouns as well as, in at least some dialects, full DPs, is presumably due to the plain fact that "most questions will be couched in the second person singular" (Davis 1971, 332).

As expounded at the beginning of this section, these claims must be taken with a grain of salt, since, to all appearances, they are flawed to varying degrees.

In the context of the analysis of an extract from a prose work of colloquial Dominican Spanish from the second half of the 18th century, Granda $(1991,86)$ encounters a single instance of whSV order in a direct interrogative with a non-argumental wh-expression ([...] cómo usted cojio tanto oro que llevo a España, de la isla Española [...]? 'How did you get so much gold that you took to Spain from the isle of Hispaniola?'). Whether this isolated example provides evidence, as he claims, for the use of such word order by at least some social strata at the time indicated or rather follows from other factors, is an issue that future investigation based on more 


\section{Previous approaches to $w h S V$ order in varieties of Caribbean Spanish}

Not only is the literature far from agreeing on the frequency of whSV order in interrogatives in varieties of Caribbean Spanish as well as on the kind(s) of preverbal subject, but also on the approach to be adopted to account for such order in general and the issues of its frequency and the kind(s) of preverbal subject in particular. In effect, approaches to the phenomenon of $w h \mathrm{SV}$ order are manifold and strongly divergent, focusing primarily on its origin and extending occasionally to its frequency and the specific nature of the preverbal subject. The approaches put forth adopt either an extralinguistic or an intralinguistic reasoning. While the latter line of reasoning is multifaceted, invoking one or several domains of grammar (morphology, phonology, pragmatics, syntax), the former exclusively draws on the notion of language contact.

Contact with another language has been repeatedly put forward in the literature. In effect, it has been generally argued that there was contact with either English (inter alia Kany 1945; Gili Gaya 1966; Davis 1971; López Morales 1992; Ordóñez \& Olarrea 2006) or some African substrate (inter alia Kany 1945; Otheguy 1973; Pérez Guerra 1989; Granda 1991; 1994; Green 1997). However, this extralinguistic approach has been challenged by numerous researchers.

An objection often raised regarding English relates to the lexicon of the lowest occupational classes that extensively or even constantly use colloquial varieties, in which whSV order is typically encountered (cf. Section 3). This lexicon manifests few, if any, relevant borrowings, a state of affairs that is strongly suggestive of the absence of any contact with English culture (inter alia Navarro Tomás 1948; Pérez Sala 1973; Lantolf 1980b; Morales 1986b; Jiménez Sabater 1999). Furthermore, whSV order has usually not been noted "among Mexican or Chicano speakers" (Lipski 1977, 61). ${ }^{25}$ Fundamentally, such word order predates the time when English started exerting influence (RAE 2009b).

Contact with an African substrate, on the other hand, is altogether dubious, since it is not verifiable (Núñez Cedeño 1983; Heap 1990; Ordóñez \& Olarrea 2001). Moreover, whSV order fails to be encountered in other 'Africanized' varieties (Heap 1990), and the languages spoken by the slaves imported from Africa were most probably typologically distinct and, presumably, did not all admit such word order (Núñez Cedeño 1983; Green 1997). Essentially, whSV order has been observed in "non-Africanized dialects of Spanish" (Lispki 1994:113) (cf. footnote 2).

In view of the "highly suspect" (Lantolf 1980b, 206) (cf. also Quirk 1972) nature of approaches based on the notion of language contact as well as the general absence of other extralinguistic approaches, an approach bearing on one or several intralinguistic factors seems preferable. In fact, many such approaches have been put forth in the literature. In what follows, I shall succinctly explain these in thematic order.

Starting with purely syntactic approaches, it has been argued that whSV order is originally due to a "fusion" of yes/no-interrogatives with SV order such as ¿Tú quieres? 'Do you want it?' and wh-interrogatives with a null subject like ¿Qué quieres? 'What do you want?' (Kany 1945). In a similar vein, $w h \mathrm{SV}$ order has been repeatedly ascribed to analogy, viz. with

evidence coming from large-scale quantitative analyses of pre-20th century texts will have to settle.

25 Cf., however, footnote 2. Further investigation is needed to decide on the issue of the availability of $w h \mathrm{SV}$ order in Mexican varieties. What is yet relevant for the present discussion is that reports on non-inversion of the subject and the verb in simple argumental $w h$-interrogatives in these varieties are virtually absent. 
one of the following constructions: (i) wh-interrogatives containing a null subject and, fundamentally, a directly preverbal oblique pronoun, such as ¿Qué te pasa? 'What happens to you?', (Padrón 1948); (ii) interrogatives with non-heavy non-argumental wh-expressions such as por qué 'why' that allow for non-inversion of the subject and the verb in Spanish (Herrero 1992); (iii) yes/no-interrogatives that generally allow for non-inversion of the subject and the verb in Spanish (Bergen 1976; cf. also Lipski 1977); (iv) replies that frequently display SV order (Lapesa 1992). Moreover, whSV order has been argued to continue a word order already encountered in Vulgar Latin and, to a minor extent, in pre-modern Peninsular Spanish (Lipski 1990; Lapesa 1992). ${ }^{26}$

Concerning approaches bearing on morpho-syntactic aspects, a fair number of these directly or indirectly relate to the status of subject pronouns by invoking (i) the establishment of an additional paradigm of subject pronouns that are 'clitic' in the sense of Cardinaletti \& Starke (1999), essentially as a compensation for the ambiguity ensuing from the loss of verbal agreement morphology (inter alia Quirk 1972; Lipski 1977; 1990; Contreras 1984; 1989; Heap 1990; Cabrera-Puche 2008), ${ }^{27}$ (ii) the extensive use of subject pronouns and their generally preverbal positioning in declaratives in varieties of Caribbean Spanish (inter alia Lantolf 1980b; López Morales 1992; Jiménez Sabater 1999; Martínez-Sanz 2011; Peralta Céspedes 2017), (iii) the loss of verbal agreement morphology in whose wake so-called 'Argument Agreement Licensing', a formalized condition ensuring that no element intervene between the whexpression and the verb, is discarded (Suñer 1994; cf. also Ticio 2008), (iv) the valuation of an uninterpretable nominative Case feature whenever speakers of varieties of Caribbean Spanish

\section{Cf. footnote 4.}

27 The erosion in verbal agreement morphology relates principally to the pronunciation in varieties of Caribbean Spanish of the inflectional suffix $-s$ marking non-deferential second person singular in all tenses but the preterite indicative. It has been commonly observed that this marker, pronounced /s/ in General Spanish, has been phonologically lost in "the majority of the population" (Andrade 1930, 10-11) from the Caribbean as early as the late 1920s, while being aspirated only among higher strata (inter alia Henríquez Ureña 1940; Jorge Morel 1978; Terrell 1982; Lipski 1977; 1994; Alba 2004; 2009a). Glossing over diastratic differences, this salient consonant apocope results from an original phonological change of $/ \mathrm{s} /$ into an aspirate and, subsequently, into zero $(/ \mathrm{s} />/ \mathrm{h} />\varnothing)$. Along with the absence of the non-deferential second person plural subject pronoun vosotros/vosotras in Latin American Spanish varieties more generally (inter alia Lenz 1920; Gili Gaya 1966; Solé \& Solé 1977; Olloqui de Montenegro 1984; Lipski 1990), the phonological loss of verbal final /s/ has led to a fair reduction in the number of distinct inflections marking person and number in Caribbean varieties, as first pointed out by Andrade (1930, 10-13): "The loss of the final $s$ has brought about the assimilation of the second person singular to the third person in all the tenses except the preterite. This together with the fact that the second person plural is never used, has reduced the inflection of the verb to four forms: first and third singular, and first and third plural, eliminating also the distinction between the intimate and the formal manner of address, so far as the verb is concerned". In effect, with a number of tenses (imperfect indicative, pluperfect indicative, conditional, conditional perfect, present subjunctive, perfect subjunctive, imperfect subjunctive, pluperfect subjunctive, future subjunctive, future perfect subjunctive), the reduction in verbal agreement morphology is even more extensive, in that verbal inflections for first, non-deferential second as well as third person singular "coincide" (Fernández Soriano 1989, 231) in form in all varieties of Spanish (cf. also inter alia Brakel 1980; Olloqui de Montenegro 1984; Ranson 1991; Cameron 1992; Toribio 2000b). For extensive discussion on the putative impact of the loss in verbal agreement morphology on the extensive use of subject pronouns in Caribbean varieties (cf. Section 5) (the so-called functional (compensation) hypothesis), cf. inter alia Davis (1971); Lipski (1977; 1994); Hochberg (1986a;b); Ranson (1991); Cameron (1992; 1996). For related discussion on Andalusian Spanish dialects, cf. inter alia Alvar (1955); Mondéjar (1970); Carbonero Cano (1982a;b); Miró Vera \& de Pineda (1990); Ranson (1991). 
access a mentally co-present innovative non-null subject variety (Toribio 1993; 2000a;b cf. also Cabrera-Puche 2008), (v) the existence of a paradigm of subject pronouns that are 'weak' in the terminology of Cardinaletti \& Starke (1999) and that remnant-move along with the verb (Ordóñez \& Olarrea 2001; 2006).

Regarding approaches that exclusively rely on phonology, it has been contended that $w h \mathrm{SV}$ order is due to an alternative alternating stress pattern affecting initially $w h$ interrogatives with a null subject and a left-peripheral topic, such as Tú ¿qué quieres? 'You, what do you want?', to licence stress on both the wh-expression and the verb by means of an intervening unstressed pronominal subject (Davis 1971; cf. also Quirk 1972).

As far as approaches are concerned that uniquely draw on pragmatics, it has been proposed that whSV order is pragmatically marked, in that it is mainly employed to express inquisitive interest, surprise, admiration or rebuke (Lapesa 1992; Rivas \& Brown 2011).

As to approaches that are based, along with pragmatics, on syntax, it has eventually been suggested that whSV order is the outcome of a tendency "to place nonasserted/presupposed subjects consistently in a thematic position" (Suñer \& Lizardi 1995, 196), possibly appended by the availability of extra structure in varieties of Caribbean Spanish (Gutiérrez-Bravo 2008).

Having briefly explained the vast number of intralinguistic approaches to the phenomenon of whSV order in interrogatives in varieties of Caribbean Spanish, in the remainder of this section I will point out a set of major problems that affect many, if not all of these approaches. ${ }^{28}$

Most approaches leave unexplained the fact that $w h \mathrm{SV}$ order in interrogatives, in particular those with a simple argumental wh-expression, is mainly, if not exclusively, encountered in Caribbean varieties. Also, the vast majority of approaches have nothing to say about the commonly noted differences in frequency regarding the preverbal occurrence of subject elements: as detailed in Section 2, it is generally observed that some pronominal subjects show up more frequently in preverbal position than others and that non-pronominal subjects occur comparatively seldom in this position. In addition, a number of approaches are based on the spurious notions that full DP subjects are excluded with whSV order, that subject pronouns are used categorically and that the latter elements occur mandatorily in preverbal position. Still, in $w h$-interrogatives, preverbal full DP subjects are arguably possible (cf. Section 2), null subjects are (still) employed (inter alia Pérez Sala 1971; 1973; Toribio 2000a; Ordóñez \& Olarrea 2006; Cabrera-Puche 2008; Brown \& Rivas 2011), and pronominal subjects can appear in postverbal position as well (inter alia Gili Gaya 1966; Cameron 1992; D'Introno 2000; Toribio 2000a; Ordóñez \& Olarrea 2006). As to the various approaches that draw on analogy, one may object with Lantolf $(1980 \mathrm{~b}, 206)$ that these "do[...] nothing more than allude to a possible relationship between the structures and do[...] not undertake to show precisely how one could have influenced the other." Lastly, regarding eventually those approaches that build on the loss of verbal agreement morphology, they leave unexplained the fact that, in varieties such as Andalusian, Argentinian, and Chilean, which show the same kind of loss (inter alia Alvar 1955; Carbonero Cano 1982a;b; Rodríguez-Izquierdo 1982; Miró Vera \& de Pineda 1990; Ranson 1991), whSV order is not encountered (Quirk 1972; Lipski 1977; RAE 2009b).

As matters stand, none of the intralinguistic approaches to $w h \mathrm{SV}$ order in interrogatives in varieties of Caribbean Spanish are free from problems. In effect, despite their occasional persuasiveness, they all eventually fall short of satisfactorily capturing the phenomenon under investigation. This state of affairs underpins the persistent relevance of the issue of $w h \mathrm{SV}$ order in varieties of Caribbean Spanish also from a theoretical point of view. In the following section,

Note that each of the intralinguistic approaches just expounded meets with further problems, whose detailed discussion would yet be tedious and is therefore dispensed with. 
I shall outline an approach to this issue which, essentially, takes into consideration other (morpho-)syntactic hallmarks of varieties of Caribbean Spanish and draws on fundamental insights into the fairly related situation in medieval French.

\section{An alternative approach to $w h S V$ order in varieties of Caribbean Spanish}

To account for the preverbal occurrence of subjects in simple non-argumental $w h$-interrogatives in varieties of Caribbean Spanish, I deem it necessary that the picture to be taken into consideration extend beyond such interrogatives and comprise other conspicuous traits of these varieties, especially Dominican Spanish, as well. I hereby concur with relevant aspects of previous approaches (inter alia Lantolf 1980b; Toribio 1993; 2000; Jiménez Sabater 1999; Ordóñez \& Olarrea 2001; 2006; Camacho 2008). As the following discussion will show, the traits to be likewise considered are all highly suggestive of the existence of an additional paradigm of subject pronouns that are not strong, but rather 'deficient' in the sense of Cardinaletti \& Starke (1999), who employ this term to refer to particular types of pronouns underlying a number of restrictions in several fields of grammar (syntax, morphology, phonology, pragmatics) as compared to strong pronouns and nominals, both of which behave identically in the relevant respects. ${ }^{29}$

Varieties of Caribbean Spanish are renowned for the extensive use of (referential) subject pronouns in declaratives (inter alia Gili Gaya 1943; 1966; Hochberg 1986a; Morales 1986a;b; 1997b; 1999; Cameron 1992; 1993; 1995; 1996; Toribio 2000a;b). This relates directly to the intriguing observation that the occurrence of these elements is not restricted to contexts in which they are interpreted as either emphatic or contrastive, as is usually the case in General Spanish, but, essentially, extends to contexts in which such interpretations are absent, as (20) illustrates for Dominican Spanish.

(20) a. Yo no puero hablá mucho poke yo estoy sin comé. 'I cannot talk a lot, since I have not eaten.' (Green 1997, 135)

b. Bueno m'hijo, todo lo que tú me pidas yo te lo doy, Dominican Spanish pero tu carrera tú tienes que hacerla tú.

'Well, my son, all you demand from me I will give you, but your career you have to make it for yourself.' (Toribio 2000b, 319)

As shown in (21), this was already the case in Dominican Spanish in the late 1920s.

(21) Entonse él se marchó a vel si hayaba su do helmano.

Dominican Spanish

Entonse él yegó donde la vieja. [...] — Mi suiso, ¿tú

no toma café?

'Then he left to search for his two brothers. Then he arrived at the place where the old lady was. - My darling, won't you have coffee?' (JuCa, illiterate, 18, Seibo, 63)

In the literature, subject pronouns as those highlighted in (20) and (21) are commonly conceived of as 'redundant' (inter alia Gili Gaya 1943; 1966; Lipski 1994; Toribio 2000a;b; Ordóñez \& Olarrea 2001; 2006; Ortiz López 2009a;b; 2016). As such, they hardly lend themselves to an analysis as strong elements. In fact, it seems more appropriate to consider them 'weak' in the sense of Cardinaletti \& Starke (1999) (cf. also Pérez-Leroux 1993; Lispki

Specifically, as a function of their particular restrictions, Cardinaletti \& Starke (1999:168) distinguish two types of deficient pronouns, viz. 'weak' and 'clitic' pronouns, referring, respectively, to "mildly deficient pronouns" and "severely deficient pronouns". 
1994; Ordóñez \& Olarrea 2001; 2006; Camacho 2008; RAE 2009a;b), i.e. structurally deficient, yet phrasal argumental elements that are 'deaccented' (RAE 2009a, 1179; cf. also Davis 1971, 332; Heap 1990, 32), much like their counterparts in modern standard French, "a notoriously non-pro-drop language" (Pollock 1989, 381,fn.17). ${ }^{30}$ Unlike the latter, however, which can additionally occur (directly) postverbally, the pertinent subject pronouns in varieties of Caribbean Spanish exclusively appear in directly preverbal position (inter alia Gili Gaya 1943; 1966; Lipski 1994; Toribio 2000a;b; Ordóñez \& Olarrea 2001; 2006; Ortiz López 2009a;b; 2016), possibly separated from the verb by the negative scope marker no 'not' and oblique pronouns, as in (20) and (21) above.

A further trait which is strongly indicative of the existence of subject pronouns that are not strong is the occurrence of what seems to be a subject expletive in at least some dialects of Dominican Spanish (inter alia Henríquez Ureña 1939; 1940; Jorge Morel 1978; Toribio 2000a;b; Camacho 2008; 2013; Pöll 2015). ${ }^{31,32}$ As (22) illustrates, "impersonal and meteorological verbs, unaccusative predicates, impersonal passives, and other constructions in which transitives are used intransitively" (Bullock \& Toribio 2009, 56) can occur with (directly preverbal) ello. This is categorically excluded in General Spanish (inter alia Hanssen 1913; Bordelois 1974; Suñer 1982a;b; Flores-Ferrán 2002; 2004; Ortiz López 2009b) ${ }^{33}$

(22) a. porque realmente ello hay personas que ...

Dominican Spanish 'since, really, there are people that ...' (Bullock \& Toribio 2009, 69)

b. Ello estaba lloviendo. 'It was raining.' (Alba 2004, 128)

Dominican Spanish

Given that subject expletives are semantically vacuous, their interpretation as either emphatic or contrastive is strictly excluded. Consequently, such elements cannot form part of the paradigm of strong subject pronouns and, therefore, must have a different morpho-syntactic status. Independent evidence for this reasoning is provided by the observation that, unlike strong subject pronouns (cf. (23a)), the subject expletive ello cannot be separated from the verb by elements other than the negative scope marker no 'not' and oblique pronouns, thus excluding the non-adjacency resulting e.g. from an intervening parenthetical (cf. (23b)) (Suñer 2003,

30 Cf. Zimmermann (2016) for a summary discussion of aspects of modern standard French referred to in this section.

31 As indicated in the text, the phenomenon under discussion is reportedly restricted, as it has been exclusively observed in dialects of mainly the rural Cibao region in the northwest of the Dominican Republic. Cf. Camacho (2008) for an approach to the restriction of the phenomenon at issue to these dialects.

The analysis in terms of a subject expletive has been challenged by Silva-Villar (1998) and Hinzelin \& Kaiser (2007), who instead argue for an analysis of the pertinent subject pronoun as, respectively, a topic/CP expletive and a discourse marker (cf. also Gupton \& Lowman 2013; Ortiz López 2016). Cf. Barme (2011), Martínez-Sanz (2011), Camacho (2013), and Pöll (2015) for extensive discussion and a rebuttal of such alternative analyses. Cf. also Suñer (2003).

Note, incidentally, that the use of ello at issue is highly stigmatized (inter alia López Morales 1992; Cabrera-Puche 2008; Camacho 2008; 2013; Alba 2009a;b; Bullock \& Toribio 2009). In effect, such use is considered to manifest speakers' belonging to or descent from the lowest social strata as well as lack of education, subjecting them to ridicule, and is therefore avoided, particularly among young, educated speakers originating from the Cibao region. Cf. Alba (2004; 2009a;b) and Klump (2017) for extensive discussion on linguistic insecurity in speakers of Dominican Spanish. 
$351) .^{34}$

(23) a. Él, a mi parecer, es muy simpático.

General Spanish

'He, it seems to me, is very nice.' (Suñer 2003, 351)

b. *Ello, a mi parecer, no sería malo estudiar.

'It seems to me that it would not be wrong to study.' (Suñer 2003, 351)

What makes varieties of Caribbean Spanish moreover stand out, while being at the same time strongly suggestive of the existence of weak subject pronouns, is the use of the third person masculine plural subject pronoun, ellos, to refer to non-specific, i.e. antecedentless, third person plurals, as shown in (24) (inter alia Avila-Jiménez 1995; Toribio 2000b; Lapidus \& Otheguy 2005; Ortiz López 2009b; Martínez-Sanz 2011). In General Spanish, the subject pronoun must be null in such cases (inter alia Cifuentes 1980; Suñer 1983; Jaeggli 1986; Ranson 1991; Camacho 2008; 2013). ${ }^{35}$

(24) Si yo voy a Santo Domingo o Venezuela, o Ecuador

Puerto Rican Spanish

o cualquiera de estos países a buscar un trabajo,

solamente por la simple razón de que estudié en

Nueva York y sé inglés, ellos son capaz de quitarle

el trabajo a un empleado de ellos para dármelo a mí

simplemente porque yo soy un americano.

'If I go to Santo Domingo or Venezuela or Ecuador or any of these countries to look for work, only for the simple reason that I studied in New York and know English, they are capable of taking away a job from an employee of theirs to give it to me for the simple reason that I am American.' (Lapidus \& Otheguy 2005, 165)

The use of ellos to refer to non-specific third person plurals is already found in Dominican Spanish in the late 1920s, as (25) illustrates.

(25) La gente de la ciudad tenía que llevarles [= a las culebras]

Dominican Spanish

comida todos los días. Pero una vez se cansaron de estarles

llevando, y la cosas andaban muy mal por la ciudad [...].

Entonces la gente empezó a recoger de lo mejor que tenían

para llevárselo al bosque, pero cuando llegaron al bosque,

se desataron esas culebras furiosas y no hacían más que

morderlos, y ellos salieron tendidos para el pueblo.

'The people from the city had to bring them [= the snakes] food every day. But once they got tired of bringing it to them, and things went bad for the city. Then the people began to gather the best they had to take it to the woods, but when they arrived at the

34 A cursory examination of the established corpus of Dominican Spanish from the late 1920s obtained no pertinent instances of ello. This is somewhat unexpected, given that the subject expletive ello is well attested with elder speakers (Cabrera-Puche 2008), an observation which suggests that ello was used back then as it is used nowadays and had thus already developed into an expletive. Further research on the diachrony of the use of ello is needed to decide on this issue.

35 An instance of non-specific ellos in Peninsular Spanish is yet encountered on a 2018 promotional poster of the US movie Death Wish (entitled El Justiciero in Spain), whose tagline starts off as in (i).

(i) Ellos acabaron con su familia ...

'They came for his family ...' 
woods, these raging snakes erputed and did nothing but bite them, and they set off as quickly as possible for the city.' (JoCi, literate, 25, San José de las Matas, 248)

Another salient characteristic of varieties of Caribbean Spanish that appears to be in favor of the existence of subject pronouns other than strong ones is the possibility of the cooccurrence of a full subject DP and a coreferential preverbal third person subject pronoun (él, ella, ellos, ellas) in the same clause (cf. (26)) (Pérez Sala 1971; Otheguy \& Zentella 2007; Camacho 2008). Such co-occurrence is impossible in General Spanish (Otheguy 1973; Camacho 2008).

a. Carlos él llegó.

'Carlos arrived.' (Otheguy \& Zentella 2007, 279)

b. María, ella cocina muy bien.

Caribbean Spanish

'María cooks very well.' (Camacho 2008, 422)

Dominican Spanish

(27) is an illustration from Dominican Spanish in the late 1920s that in fact displays the occurrence in the same clause of two instances of one and the same pronominal subject.

(27) Pero él, cuando eya se fué, él se fué detrá de eya.

Dominican Spanish

'Yet he, when she went away, he went after her.' (FéAn, illiterate, peasant, 30, Seibo, 102)

An additional trait of varieties of Caribbean Spanish that is again suggestive of the existence of weak subject pronouns is the use of third person subject pronouns (él, ella, ellos, ellas) with non-human antecendents, as in (28) (Toribio 2000a;b; Lunn 2002; Bullock \& Toribio 2009). In General Spanish, such use is generally excluded, and null subjects are usually employed in cases of subsequent reference (inter alia Jensen 1973; Suñer 1982a; Cameron 1992; 1993; 1995; Toribio 2000b; Flores-Ferrán 2002; 2004).

a. $E ́ l[=$ el río $]$ tiene poca agua. 'It [ = the river] has little water.' (Toribio 2000a, 629; 2000b, 320)

Dominican Spanish

b. Pero yo no sé que le $\mathrm{i}_{\mathrm{i}}$ pasó [a la camioneta $\mathrm{a}_{\mathrm{i}}$ porque

Dominican Spanish ella $a_{\mathrm{i}}$ tiene gasolina y ella $a_{\mathrm{i}}$ estaba caminando bien.

'But I do not know what happened to it [= the bus], since it had gas and it was working well.' (Bullock \& Toribio 2009, 57)

The use of third person subject pronouns to refer to non-human antecendents is likewise attested in Dominican Spanish from the late 1920s, as exemplified in (29).

(29) Depué de mucho caminar se encontraron con una

Dominican Spanish

serpiente $_{i}$ que se etaha comiendo un cabayo, y el

cabayo era de la hija del rey, que había andado

por ayí, y eya había tumbado el cabayo al suelo y

quería comerse al cabayo y a la muchacha. El

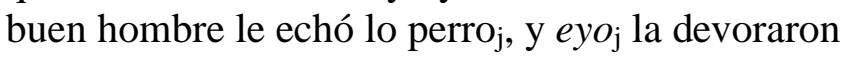

en un abrir y serrar de ojo.

'After having travelled for a long time, they met a snake that was eating a horse, and the horse belonged to the king's daughter, who had passed there, and it had knocked down the horse to the ground and wanted to eat the horse and the girl. The good man set the 
dogs on it, and they gulped it down in a flash.' (JuAr, illiterate, 80, Higüey, 300)

A further characteristic that has been solely reported for Puerto Rican Spanish relates to phonology. Specifically, with what Cameron $(1992,109)$ refers to as "discourse markers",36 which, unlike in General Spanish, regularly occur with a subject pronoun in varieties of Caribbean Spanish, viz. phrases such as tú sabe(s) 'you know', tú no sabe(s) 'you have no idea', tú entiende(s) 'you understand', tú ve(s) 'you see', phonological proclisis of the subject pronoun, if not its fusion with the verb (cf. (30)), is frequent in at least Puerto Rican Spanish (López Morales 1983; Cameron 1992). ${ }^{37}$

[tsa] (= tú sabe $(s))$

Puerto Rican Spanish

'you know' (Cameron 1992, 110)

These phonological traits are clear indications not only of the structural deficiency of the subject pronoun at issue, but also of its atonicity and, therefore, underpin the claim of the existence of subject pronouns other than strong ones in varieties of Caribbean Spanish.

Intriguingly, many of the observations presently put forth are highly reminiscent of a typologically related pre-modern variety, namely that usually referred to as Old French (9th13th century). French is commonly taken to have evolved from a null into a non-null subject language (inter alia Adams 1987; Roberts 1993; Vance 1997). Unlike modern French, which has two paradigms of strong and weak subject pronouns, respectively, most of which are distinct in form, Old French is traditionally considered to have a single paradigm of subject pronouns constituting strong elements.

This view, however, has been challenged, as it has been argued that Old French additionally has a paradigm of weak subject pronouns, being almost identical in form to their strong counterparts (inter alia Foulet 1935/36; Skårup 1975; Marchello-Nizia 1999; Zimmermann 2018a; cf. also Roberts 1993; Vance 1995). The two major pieces of evidence in favor of such an alternative approach tie in with some of the pieces of evidence given above to corroborate the claim of the existence of weak subject pronouns in varieties of Caribbean Spanish. In particular, subject pronouns in Old French can occur in the same clause along with another coreferential subject element, even one of the same type (cf. (31)), and participate, at least as regards the first person singular, in phonological proclisis ( $\left.j e /[3 \supset] \rightarrow j^{\prime} /[3]\right)$ (cf. (32)).

Jou je n'irai.

Old French

'I will not go.' (Le Couronnement de Renard 568, quoted from Foulet 1935, 307)

que $j$ 'en recevroie tel cop

Old French

'that I would receive such a blow from it' (La Queste del Saint Graal 30, 24, quoted from Vance 1995, 303)

Crucially, Old French stands out due to two further morpho-syntactic traits which have generally been left out of consideration in the context of the debate on the number of paradigms of subject pronouns in the history of French and which are, in turn, strongly suggestive of the existence of a paradigm of weak subject pronouns. Specifically, as in varieties of Caribbean Spanish, referential subject pronouns in Old French are frequently used in contexts in which

36 Cf. Cameron (1992, 109-112) for further explanation.

37 A cursory examination of the established corpus of Dominican Spanish from the late 1920s yielded no instances of phonological reduction of the discourse markers at issue. Since such discourse markers are generally absent in this corpus, the issue remains to be settled whether phonological proclisis of $t u ́$ was possible in such contexts back then. 
they are interpreted as neither emphatic nor contrastive (cf. (33)) (inter alia Adams 1987; Vance 1997; Zimmermann 2014; 2018a;b).

(33) Treze anz mist li reisi á faire sun paleis od tutes les apurtenances, é puis que $i l_{\text {i }}$ out fait le temple

Deu é sun demeine paleis é quanque $i l_{\text {i }}$ out desíred

a faire, nostre Seignur j li aparut altre feiz si cume

$i l_{\mathrm{j}}$ out fait en Gabaón.

'The king needed thirteen years to build his palace together with his near relations, and when he had built the temple of the Lord and his own palace and all what he had desired to do, the Lord appeared to him another time, just as He had done at Gibeon.' (Li Quatre Livre des Reis, p.133, quoted from Zimmermann 2014, 2-3; 2018b, 72)

Fundamentally, as has been claimed with regard to some dialects of Dominican Spanish, Old French evinces the occurrence of a subject expletive, il, (cf. (34)) (Zimmermann 2014; 2018a;b).

a. $I l$ nen i ad chevalier ne barun

Old French 'There was no knight nor baron' (La Chanson de Roland, p.453, quoted from Zimmermann 2018b:79)

b. que $i l$ ne plúve pur lur pecchíe

Old French 'because it does not rain on account of their sin' (Li Quatre Livre des Reis, p.130f., quoted from Zimmermann 2018b:79)

In view of the compelling evidence provided from varieties of Caribbean Spanish as well as the many parallels with a typologically related language, it seems natural then to assume that varieties of Caribbean Spanish have developed an additional paradigm of subject pronouns that are weak and (almost) identical in form to their strong counterparts.

Since, as witnessed by modern standard French, local valuation of nominative Case, $\varphi$ features as well as the $\mathrm{E}$ (xtended)P(rojection)P(rinciple) feature obtains with weak subject pronouns (cf. also Suñer 2003; Camacho 2006; 2008), the development of a paradigm of such elements in varieties of Caribbean Spanish is necessarily accompanied by the projection of a dedicated argumental specifier position at the T(ense) level. In line with previous analyses (inter alia Toribio 1993; 2000a;b; Suñer 1994; Pérez-Leroux 1999; Ordóñez \& Olarrea 2001; 2006; Camacho 2008), I assume in this respect that, in varieties of Caribbean Spanish, directly preverbal subject pronouns that have neither an emphatic nor a contrastive interpretation occupy SpecTP. Unlike in null subject languages in general then, for which the projection of this position has commonly been disputed in numerous minimalist work (inter alia Duarte 1993; Speas 1994; Alexiadou \& Anagnostopoulou 1998; Ordóñez \& Treviño 1999; Ticio 2004), SpecTP is projected in varieties of Caribbean Spanish, originally with weak pronominals only and, later on, also with full DPs (cf. Section 3).

The development of a paradigm of weak subject pronouns and the concomitant establishment of SpecTP as a dedicated subject position are clearly reflective of ongoing morpho-syntactic changes in varieties of Caribbean Spanish. That this is indeed the case is underpinned by another syntactic hallmark of these varieties: the strong overall tendency towards SV order.

As a matter of fact, varieties of Caribbean Spanish show fairly strict SV order irrespective of sentence type (root as well as embedded declaratives, wh-exclamatives, rhetorical and quotative questions, relatives), the specific nature of the subject (pronominal, 
non-pronominal), its pragmatic function (topic, focus) as well as verb type (inter alia Morales 1986a;b; 1997a;b; 1999; Pérez-Leroux 1999; Toribio 2000b; Ortiz López 2009a;b; 2016; Camacho 2013). This is illustrated in (35).

a. Sí, mas o meno yo canto. Yo tengo un padrino de

Caribbean Spanish matrimonio que ése también canta porque él eh el diácono de la iglesia y él canta.

'Yes, I sing more or less. I have a best man that sings as well, since he is deacon of the church and he sings.' (Ortiz López 2009b, 95)

b. ¡Qué gordo yo estoy!

'How fat I am!' (Toribio 1993, 169)

Dominican Spanish

The development of a strict word order in varieties of Caribbean Spanish is again highly reminiscent of the evolution of word order in French. In effect, French developed from a language with strong verb-second effects into one in which inversion of the subject and the verb is severely sanctioned in the modern standard variety and (almost) absent in the modern colloquial variety. ${ }^{38}$ Note in this regard that modern colloquial French, just like varieties of Caribbean Spanish, frequently displays $w h \mathrm{SV}$ order in direct (as well as indirect) simple argumental $w h$-interrogatives with both pronominal and non-pronominal subjects.

The discussion so far has been strongly suggestive of the view that varieties of Caribbean Spanish have developed, along with SpecTP as an A-position, a paradigm of weak subject pronouns and are, moreover, in the process of moving towards rigid SV order. I consider these insights essential for accounting for non-inversion of the subject and the verb in simple argumental $w h$-interrogatives in these varieties. Specifically, I argue that the traits at issue ultimately paved the way for SV order in such interrogatives, "encroaching upon one of the few instances in which VS word order is gr[a]mmatically required" (Brown \& Rivas 2011, 41). ${ }^{39}$

On the reasonable assumption that, in varieties of Caribbean Spanish, neither the occurrence of weak subject pronouns nor the tendency towards SV order is restricted to a particular sentence type or a subset of sentence types, the null hypothesis is that weak subject pronouns show up in SpecTP in interrogatives as well (cf. also Lispki 1994; Cabrera-Puche 2008; Ortiz López 2009b). ${ }^{40}$ In effect, various pieces of evidence, to be explained in what follows, corroborate such a view.

Regarding direct non-cleft yes/no-interrogatives, in which the inversion of the subject and the verb is not mandatory in Spanish, subject pronouns in at least Dominican Spanish from the late 1920s are frequently overt and, fundamentally, appear almost consistently in directly preverbal position: ${ }^{41}$ as shown in Table (14), $69.2 \%$ of all pertinent yes/no-interrogatives have a preverbal subject pronoun.

Cf. Culbertson (2010) and Kaiser \& Zimmermann (2011) for extensive discussion.

I consider the originally mandatory nature of the inversion of the subject and the verb in interrogatives with a simple argumental wh-expression in Spanish to be responsible for the arguably delayed intrusion of preverbal subjects in this sentence type, as reflected by the relatively low percentage of particularly preverbal tú in pertinent interrogatives in the established corpus of Dominican Spanish from the late 1920s (23.3\%) as opposed to the comparatively high percentage of the corresponding null subject $(54.8 \%)$. Note, in this connection, the considerable discrepancy of this finding with that from direct non-cleft yes/nointerrogatives, given farther on in Table (14).

Fundamentally, this reasoning implies that, in interrogatives in particularly Caribbean varieties of Spanish, the verb occupies the T level, rather than the C(omplementizer) level (cf. also Suñer 1994; Ordóñez \& Olarrea 2006).

To the best of my knowledge, there are no quantitative studies on the syntax of (direct non-cleft) yes/no-interrogatives in varieties of Spanish. 


\begin{tabular}{|l|c|c|}
\hline & $\#$ & \% \\
\hline null & 39 & 29.3 \\
\hline overt preverbal & 92 & 69.2 \\
\hline overt postverbal & 2 & 1.5 \\
\hline total & 133 & 100 \\
\hline
\end{tabular}

Table (14): Nature and positioning of subject pronouns in direct non-cleft yes/nointerrogatives

Essentially, as illustrated by tú in the interrogative in (21) above, directly preverbal subject pronouns have neither an emphatic nor a contrastive interpretation and, thus, prove to be 'redundant'.

Turning to $w h$-interrogatives, it has been repeatedly noted in the literature that, with directly preverbal subject pronouns, an emphatic or contrastive interpretation is likewise consistently absent in varieties of Caribbean Spanish (inter alia Patín Maceo 1940; Gili Gaya 1966; Davis 1971; Stiehm 1987; Ordóñez \& Olarrea 2001; 2006). A case in point is the occurrence of the subject expletive ello in directly preverbal position in this type of sentence (cf. (36)).

¿Por dónde ello aparece eso?

'Where does this appear?' (Bullock \& Toribio 2009, 57)

Dominican Spanish

Moreover, as in other sentence types, subject pronouns that do not lend themselves to an interpretation as either emphatic or contrastive are restricted in their positioning in whinterrogatives, appearing exclusively in directly preverbal position. In effect, the literature essentially concurs that, in this sentence type, postverbal subjects are consistently interpreted as contrastive (inter alia Gili Gaya 1966; Quirk 1972; Cameron 1992; D’Introno 2000; Ordóñez \& Olarrea 2006).

What is also strongly suggestive of the occurrence of weak subject pronouns in, particularly, simple argumental $w h$-interrogatives in varieties of Caribbean Spanish is the crucial observation that, when appearing in directly preverbal position, subject pronouns pass three more tests which are commonly taken to be indicative of the morpho-syntactic status of subject pronouns as weak elements, as originally laid out in Kayne (1975) regarding modern French. Specifically, along with weak subject pronouns in modern standard French, directly preverbal subject pronouns in varieties of Caribbean Spanish can be neither separated from the verb by strong elements (cf. (37)) (Lispki 1994), nor modified (cf. (38)) (Ordóñez \& Olarrea 2001; 2006; Ordóñez 2016), ${ }^{42}$ nor conjoined (cf. (39)) (Ordóñez \& Olarrea 2001; 2006; Ordóñez 2016). ${ }^{43}$

42 Suñer \& Lizardi (1995) provide the example in (i), arguing that modification is yet possible in at least Puerto Rican Spanish.

(i) ¿A quién ustedes tres vieron ayer?

'Who did you three see yesterday?' (Suñer \& Lizardi 1995, 194)

Further investigation is needed to clarify matters.

43 Note that, in the established corpus of Dominican Spanish from the late 1920s, no relevant instances of separated, modified or conjoined directly preverbal subject pronouns have been detected. Although one must not readily extrapolate from the absence of particular constructions in a pre-modern corpus to their ungrammaticality at a given point in time, the non-occurrence 
(37) *¿Qué tú a veces piensas?

'What do you sometimes think?' (Lispki 1994:62,fn.4)

(38) * ¿Qué tú mismo comes?

'What do you eat yourself?' (Ordóñez \& Olarrea 2006, 74)

Caribbean Spanish

Caribbean Spanish

*¿Qué tú y él comieron?

'What did you and he eat?' (Ordóñez \& Olarrea 2001, 228; 2006, 74)

Caribbean Spanish

From the discussion in this section I conclude that $w h \mathrm{SV}$ order with pronominal subjects in simple argumental $w h$-interrogatives in Dominican, and by extension, other varieties of Caribbean Spanish, follows from the existence of a paradigm of weak subject pronouns and, concomitantly, their regular occurrence in a dedicated, directly preverbal A-position exclusively limited to subject elements, SpecTP.

The projection of this position may be naturally expected to be initially restricted to weak subject pronouns, which, in the course of time, have presumably been increasingly employed to the detriment of null subjects, possibly along the lines outlined in Sprouse \& Vance (1999) for French. Such a development would necessarily result in a constantly more frequent projection of SpecTP and, if so, have a knock-on effect on full DP subjects, in the sense that this position, which is in principle open to any kind of subject element, is 'activated' as a potential landing-site for non-weak subject elements. ${ }^{44}$ Crucially, I consider this surmised state of affairs to be at the outset of the strong overall tendency of full DP subjects in varieties of Caribbean Spanish to occur in directly preverbal position independent of their pragmatic function, verb type, and, most notably, sentence type. Regarding $w h \mathrm{SV}$ order in simple argumental $w h$-interrogatives with full DP subjects, I assume that, in those Caribbean varieties in which weak subject pronouns are recurrently employed, among which is Dominican, SpecTP has eventually come to host also full DP subjects.

of pertinent instances in the corpus may yet be tentatively considered indirect corroboration for the view that the contemporary state of affairs obtained in Dominican Spanish almost a century ago.

44 The precise conditions under which full DP subjects start moving to SpecTP remain to be determined on the basis of in-depth diachronic investigation. 


\section{Conclusion}

On the level of syntax, varieties of Caribbean Spanish have been specifically noted to additionally allow for non-inversion of the subject and the verb in interrogatives with particularly a simple non-subject argumental wh-expression. Despite being on the research agenda for almost a hundred years, the frequency and the kind(s) of subject possible with $w h \mathrm{SV}$ order are still highly controversial, much like the approaches put forth to account for it. Quantitative as well as qualitative claims range from, respectively, an infrequent to a consistent use of such word order and a strict limitation to a subset of subject pronouns to their full paradigm along with full DPs. Still, by gathering a multitude of such claims, it has been shown that, in varieties of Caribbean Spanish, whSV order appears to occur regularly with pronominal subjects. On the basis of a refined quantitative analysis of a large-scale corpus of natural speech from colloquial Dominican Spanish, which is contemporaneous to the first mention of whSV order in the literature, it has been shown that, in the late 1920s, non-inversion of the subject and the verb in direct $w h$-interrogatives (i) is possible only with tú and usted, (ii) ranges in frequency from $27.3 \%$ to $71.4 \%$, depending on the argumental nature of the $w h$-expression, and (iii) is exclusively produced by young adult speakers. Correlating these findings with claims in the literature on Dominican Spanish, it has been surmised that, in the course of the 20th and 21st centuries, restrictions on the intervening subject have become considerably relaxed, if not entirely lifted, and the use of whSV order has gained vital momentum, resulting in a high frequency. The corpus findings have furthermore been taken indicative of the innovative nature of such word order in colloquial Dominican Spanish, whose origins arguably date back to the late 19th century. As far as previous approaches to whSV order are concerned, which are manifold and essentially adopt an extra- or intralinguistic reasoning, it has been shown that none of these are free from problems. In particular, while accounts based on the notion of language contact prove to be hardly convincing in the present case, those drawing on one or several domains of grammar, albeit pervasive to a certain extent, eventually fall short of satisfactorily capturing the explanandum. In this regard, an approach has been proposed that, essentially, embraces a larger perspective, by taking into consideration traits of varieties of Caribbean, especially Dominican Spanish which seem to be intimately related to that of whSV order and by drawing on insights into the fairly similar situation in medieval French. The adoption of such a larger perspective has been shown to be strongly suggestive of the existence in varieties of Caribbean Spanish of an additional paradigm of subject pronouns which are weak and distributionally constrained to directly preverbal position. In line with standard assumptions on e.g. the standard variety of modern French, the occurrence of such elements has been argued to be accompanied by the projection of a dedicated specifier position at the $\mathrm{T}$ level that is exclusively limited to the appearance of subject elements, SpecTP. These developments have in turn been taken to be at the outset of another syntactic hallmark of varieties of Caribbean Spanish, viz. the strong overall tendency of full DP subjects towards SV order. Departing from the null hypothesis that, in these varieties, neither the occurrence of weak subject pronouns nor the projection of SpecTP are restricted to a subset of sentence types, and underpinning this hypothesis by various pieces of evidence, whSV order in interrogatives with particularly a simple non-subject argumental wh-expression has eventually been claimed to naturally follow in Dominican, and by extension, other varieties of Caribbean Spanish.

As a final note, I would like to suggest, in line with various researchers (inter alia Heap 1990; Toribio 1993; 2000a;b; Pérez-Leroux 1999; Ticio 2004; Camacho 2008; 2013), that the ongoing morpho-syntactic changes considered crucial in the context of the present investigation, viz. the development of a full-fledged paradigm of weak subject pronouns, the establishment of SpecTP as the canonical subject position, and the strive for rigid SV order 
throughout, might ultimately result in a resetting of the null subject parameter. This is in fact what happened in French, which, in its earliest stage, evinced the three changes at issue, along with the occurrence of null subjects. As these changes in varieties of Caribbean Spanish bring about a state of affairs that is ever more reminiscent of that obtaining in prototypical non-nullsubject languages and, as evinced by French, predate the resetting of the null subject parameter, they can firmly be considered precursors of this resetting. Essentially, though, if such resetting occurs at all, which, as with any kind of ongoing change, cannot be predicted with certainty, it may not necessarily be imminent. In effect, adopting once again the French perspective, the observed morpho-syntactic changes in varieties of Caribbean Spanish might well persist for centuries without the null subject parameter being reset. Whereas regarding French, the resetting took place in pre-modern times, for which the bad data problem in the Labovian sense arises, preventing a thorough technical implementation of the particulars of this resetting, varieties of Caribbean Spanish offer an exceptional opportunity in this respect, as they allow for close investigation of real-time changes in the context of longitudinal studies.

\section{References}

Adams, Marianne. 1987. Old French, null subjects, and verb second phenomena. Ph.D. thesis, University of California at Los Angeles.

Alba, Orlando. 2004. Cómo hablamos los dominicanos: Un enfoque sociolingüístico. Santo Domingo: Grupo León Jimenes.

Alba, Orlando. 2009a. "Dominicanos”. In H. López Morales (ed.), Enciclopedia del español en los Estados Unidos, 357-381. Madrid: Santillana.

Alba, Orlando. 2009b. La identidad lingüística de los dominicanos. Santo Domingo: La Trinitaria.

Alexiadou, Artemis \& Elena Anagnostopoulou. 1998. "Parametrizing AGR: Word order, vmovement and EPP-checking". Natural Language and Linguistic Theory 16: 491-539.

Alvar, Manuel. 1955. "Las hablas meridionales de España y su interés para la lingüística comparada". Revista de Filología Española 39: 284-313.

Alvarez Nazario, Manuel. 1972. La herencia lingüística de Canarias en Puerto Rico. Estudio histórico-dialectal. San Juan: Instituto de Cultura Puertorriqueña.

Alvarez Nazario, Manuel. 1981. "Relaciones histórico-dialectales entre Puerto Rico y Canarias”. In M. Alvar López (ed.), I Simposio Internacional de Lengua Española, 289-310. Las Palmas de Gran Canaria: Excmo.

Alvarez Nazario, Manuel. 1990. El habla campesina del país. Orígenes y desarrollo del español en Puerto Rico. Río Piedras: Editorial de la Universidad de Puerto Rico.

Andrade, Manuel J. 1930. Folk-lore from the Dominican Republic. NY: Stechert \& Co.

Arnaiz, Alfredo R. 1998. "An overview of the main word order characteristics of Romance". In A. Siewierska (ed.), Constituent Order in the Languages of Europe, 47-74. Berlin: Mouton de Gruyter.

Avila-Jiménez, Bárbara I. 1995. "A sociolinguistic analysis of a change in progress: Pronominal overtness in Puerto Rican Spanish". Cornell Working Papers in Linguistics 13: 25-47.

Barme, Stefan. 2011. "Zur Verwendung des Pronomens ello im dominikanischen Spanisch". Zeitschrift für romanische Philologie 127(2): 352-359.

Bergen, John J. 1976. "The explored and unexplored facets of questions such as Qué tú tienes?" Hispania 59(1): 93-99.

Bordelois, Ivonne A. 1974. The grammar of Spanish causative complements. Ph.D. thesis, Massachusetts Institute of Technology.

Brakel, Arthur. 1980. "Infinitives, subjects, word order, and case in Portuguese and Spanish". 
Hispania 63(1): 85-91.

Brown, Esther L. \& Javier Rivas. 2011. "Subject-verb word order in Spanish interrogatives. A quantative analysis of Puerto Rican Spanish". Spanish in Context 8(1): 23-49.

Buesa Oliver, Tomás. 1986. "Anotaciones sobre regionalismos peninsulares en el español de América”. Boletín de la Asociación Europea de Profesores de Español 34-35: 107-126.

Bullock, Barbara E. \& Almeida J. Toribio. 2009. "Reconsidering Dominican Spanish: Data from the rural Cibao". Revista Internacional de Lingüística Iberoamericana 7(2): 49-73.

Burunat, Silvia, Julio Burunat \& Elizabeth D. Starčević. 1987. El español y su sintaxis. NY, Berne, Frankfurt a.M.: Lang.

Butt, John \& Carmen Benjamin. 2011. A new reference grammar of modern Spanish. London, NY: Routledge, 5th edn.

Cabrera-Puche, María J. 2008. Null subject patterns in language contact: The case of Dominican Spanish. Ph.D. thesis, The State University of New Jersey.

Camacho, José. 2006. “Do subjects have a place in Spanish?” In C. Nishida \& J.-P.Y. Montreuil (eds.), New perspectives in Romance linguistics. Volume I: Morphology, syntax, semantics, and pragmatics. Selected papers from the 35th Linguistic Symposium on Romance Lanugages (LSRL), Austin, Texas, February 2005, 51-66. Amsterdam, Philadelphia: Benjamins.

Camacho, José. 2008. "Syntactic variation: The case of Spanish and Portuguese subjects". Studies in Hispanic and Lusophone Linguistics 1(2): 415-433.

Camacho, José. 2013. Null subjects. Cambridge: Cambridge University Press.

Cameron, Richard. 1992. Pronominal and null subject variation in Spanish: Constraints, dialects, and functional compensation. Ph.D. thesis, University of Pennsylvania.

Cameron, Richard. 1993. "Ambiguous agreement, functional compensation, and nonspecific tú in the Spanish of San Juan, Puerto Rico, and Madrid, Spain”. Language Variation and Change 5: 305-334.

Cameron, Richard. 1995. "The scope and limits of switch reference as a constraint on pronominal subject expression". Hispanic Linguistics 6/7: 1-27.

Cameron, Richard. 1996. "A community-based test of a linguistic hypothesis". Language in Society 25: 61-111.

Cantero, Jorge G. 1978. "Peculiaridades en el empleo del pronombre personal yo en el habla culta de la ciudad de México". Anuario de Letras 14: 233-237.

Carbonero Cano, Pedro. 1982a. El habla de Sevilla. Sevilla: Servicio de Publicaciones del Ayuntamiento.

Carbonero Cano, Pedro. 1982b. "Polimorfismo y funcionalidad en en [sic] uso lingüístico de hablantes andaluces". In P. Carbonero Cano (ed.), Sociolingüística andaluza 1, 47-56. Sevilla: Universidad de Sevilla.

Cardinaletti, Anna \& Michal Starke. 1999. "The typology of structural deficiency: A case study of the three classes of pronouns". In H. van Riemsdijk (ed.), Clitics in the languages of Europe, 145-233. Berlin, NY: Mouton de Gruyter.

Cifuentes, Hugo. 1980. "Presencia y ausencia del pronombre personal sujeto en el habla culta de Santiago de Chile". Boletín de Filología 31(2): 743-752.

Contreras, Heles. 1984. "Multiple questions in English and Spanish". In P. Baldi (ed.), Papers from the XIIth Linguistic Symposium on Romance Languages, 121-133. Amsterdam, Philadelphia: Benjamins.

Contreras, Heles. 1989. "Closed domains". Probus 1(2): 163-180.

Culbertson, Jennifer. 2010. "Convergent evidence for categorial change in French: From subject clitic to agreement marker". Language 86: 85-132. 
D’Introno, Francesco. 2000. “Teoría generativa y estudios sintácticos sobre el español de Puerto Rico y el Caribe". Revista de Estudios Hispánicos 27(1): 107-147.

Davis, J. Cary. 1971. “Tú, ¿qué tú tienes?” Hispania 54(2): 331-333.

Duarte, M. Eugênia. 1993. "Do pronome nulo ao pronome pleno: A trajetória do sujeito no português d'aquém e d'além-mar ao final do século XIX”. In I. Roberts \& M. Kato (eds.), Português brasileiro. Uma viagem diacrônica, 107-128. Campinas: Editora da Unicamp.

Dumitrescu, Domnita. 2016. "Oraciones interrogativas indirectas y otras estructuras". In J. Gutiérrez Rexach (ed.), Enciclopedia lingüística hispánica. Volumen 1, 761-772. London, NY: Routlegde.

Fernández Soriano, Olga. 1989. "Strong pronouns in null-subject languages and the Avoid Pronoun Principle". MIT Working Papers in Linguistics 11: 228-239.

Flores-Ferrán, Nydia. 2002. Subject personal pronouns in Spanish narratives of Puerto Ricans in New York City. A Sociolinguistic Perspective. Munich: Lincom Europa.

Flores-Ferrán, Nydia. 2004. "Spanish subject personal pronoun use in New York City Puerto Ricans: Can we rest the case of English contact?" Language Variation and Change 16: 4973.

Fontana, Josep M. 1994. “A residual A-bar position in Spanish”. In E. Duncan, D. Farkas \& P. Spaelti (eds.), The proceedings of the Twelfth West Coast Conference on Formal Linguistics, 233-250. Stanford, CA: CSLI.

Foulet, Lucien. 1935/1936. "L'extension de la forme oblique du pronom personnel en ancien français". Romania 61: 257-315; 401-463. Romania 62: 27-91.

Gili Gaya, Samuel. 1943. Curso superior de sintaxis española. S.n.: Minerva.

Gili Gaya, Samuel. 1966. Nuestra lengua materna. Observaciones gramaticales y léxicas. San Juan: Instituto de Cultura Puertorriqueña.

Granda, Germán de. 1991. "Un rasgo sintáctico caribeño en el español dominicano del siglo XVIII (la no inversión del pronombre sujeto en oraciones interrogativas)". Anuario de Lingüística Hispánica 7: 81-95.

Granda, Germán de. 1994. "Acerca de la génesis de un rasgo sintáctico del español antillano. La no transposición del sujeto pronominal en oraciones interrogativas". In G. de Granda (ed.), Español de América, español de África y hablas criollas hispánicas. Cambios, contactos y contextos, 172-188. Madrid: Gredos.

Green, John N. 1988. "Spanish". In M. Harris \& N. Vincent (eds.), The Romance languages, 79-130. London, Sydney: Croom Helm.

Green, Katherine R. 1997. Non-standard Dominican Spanish: Evidence of partial restructuring. Ph.D. thesis, City University of New York.

Gupton, Timothy \& Sarah Lowman. 2013. "An F projection in Cibeño Dominican Spanish". In J. Cabrelli Amaro, G. Lord, A. de Prada Pérez \& J. Elana Aaron (eds.), Selected proceedings of the 16th Hispanic Linguistics Symposium, 338-348. Somerville: Cascadilla Proceedings Project.

Gutiérrez Araus, M. Luz. 1987. "Rasgos gramaticales del español de Cuba en la novela Tres tristes tigres, de Cabrera Infante”. In M.T. Vaquero de Ramírez \& H. López Morales (eds.), Actas del I Congreso Internacional sobre el Español de América, 997-1008. San Juan: Academia Puertorriqueña de la Lengua Española.

Gutiérrez-Bravo, Rodrigo. 2008. "Topicalization and preverbal subjects in Spanish whinterrogatives". In J. Bruhn de Garavito \& E. Valenzuela (eds.), Selected Proceedings of the 10th Hispanic Linguistics Symposium, 225-236. Somerville: Cascadilla Proceedings Project.

Hadlich, Roger L. 1971. A transformational grammar of Spanish. Englewood Cliffs: PrenticeHall.

Hanssen, Federico. 1913. Gramática histórica de la lengua castellana. Halle a.S.: Niemeyer.

Heap, David J. 1990. "Les questions à sujet pronominal préposé dans les dialectes de l'espagnol des Caraïbes". Journal of the Atlantic Provinces Linguistic Association / Revue de 
l'Association de Linguistique des Provinces Atlantiques 12: 13-38.

Henríquez Ureña, Pedro. 1939. "Ello". Revista de Filología Hispánica 1(3): 209-229.

Henríquez Ureña, Pedro. 1940. El español en Santo Domingo. Buenos Aires: Universidad de Buenos Aires.

Hinzelin, Marc-Olivier \& Georg A. Kaiser. 2007. "El pronombre ello en el léxico del español dominicano". In W. Mihatsch \& M. Sokol (eds.), Language contact and language change in the Caribbean and beyond / Lenguas en contacto y cambio lingüístico en el Caribe y más allá, 171-188. Frankfurt a.M. etc.: Lang.

Hochberg, Judith G. 1986a. "Functional compensation for /s/ deletion in Puerto Rican Spanish". Language 62(3): 609-621.

Hochberg, Judith G. 1986b. "/s/ deletion and pronoun usage in Puerto Rican Spanish". In D. Sankoff (ed.), Diversity and diachrony, 199-210. Amsterdam, Philadelphia: Benjamins.

Jaeggli, Osvaldo A. 1986. "Arbitrary plural pronominals". Natural Language and Linguistic Theory 4:43-76.

Jensen, John B. 1973. "The feature [ \pm Human] as a constraint on the occurrence of third-person subject pronouns in Spanish". Hispania 56(1): 116-122.

Jiménez Sabater, Max A. 1977. "Estructuras morfosintácticas en el español dominicano: Algunas implicaciones sociolingüísticas". Ciencia y Sociedad 2(1): 5-20.

Jiménez Sabater, Max A. 1999. Más datos sobre el español de la República Dominicana. Santo Domingo: Secretaría de Estado de Educación y Cultura, 3rd edn.

Jorge Morel, Elercia. 1978. Estudio lingüístico de Santo Domingo. Aportación a la geografía lingiüística del Caribe e Hispano América. Santo Domingo: Taller.

Kaiser, Georg A. \& Michael Zimmermann. 2011. "On the decrease in subject-verb inversion in French declaratives". In: E. Rinke \& T. Kupisch (eds.), The development of grammar. Language acquisition and diachronic change. In honour of Jürgen M. Meisel, 355-381. Amsterdam, Philadelphia: Benjamins.

Kany, Charles E. 1945. American-Spanish syntax. Chicago: The University of Chicago Press.

Kayne, Richard S. 1975. French syntax. The transformational cycle. Cambridge, MA: The MIT Press.

Klump, André. 2017. "Entre pesimismo y lealtad - Las actitudes lingüsticas de los dominicanos". In C. Felbeck \& A. Klump (eds.), Dominicanidad / Dominicanity. Perspectivas de un concepto (trans-)nacional / Perspectives on a (trans-)national concept, 81-92. Frankfurt a.M. etc.: Lang.

Lantolf, James P. 1980a. "Constraints on interrogative word order in Puerto Rican Spanish". Bilingual Review / La Revista Bilingüe 7(2): 113-122.

Lantolf, James P. 1980b. "Evolutive change in syntax: Interrogative word order in Puerto Rican Spanish". In F.H. Nuessel, Jr. (ed.), Contemporary studies in Romance languages. Proceedings of the Eighth Annual Symposium on Romance Languages, 202-219. Bloomington: Indiana University Linguistics Club.

Lapesa, Rafael. 1992. "La interpolación pronominal en las oraciones interrogativas". In M. Ariza, R. Cano, J.M. Mendoza \& A. Narbona (eds.), Actas del II Congreso Internacional de Historia de la Lengua Española, Tomo I, 545-553. Madrid: Pabellón de España.

Lapidus, Naomi \& Ricardo Otheguy. 2005. "Overt nonspecific Ellos in Spanish in New York”. Spanish in Context 2(2): 157-174.

Lenz, Rodolfo. 1920. La oración y sus partes. Madrid: Centro de Estudios Históricos.

Liceras, Juana M. 1994. "La teoría sintáctica y los juicios de gramaticalidad: La posposición del sujeto en español”. Revista Canadiense de Estudios Hispánicos 18(2): 219-255.

Lipski, John M. 1977. "Preposed subjects in questions: Some considerations". Hispania 60(1): 61-67. 
Lipski, John M. 1990. The language of the Isleños. Vestigial Spanish in Louisiana. Baton Rouge: Louisiana State University Press.

Lipski, John M. 1994. Latin American Spanish. London, NY: Longman.

López Morales, Humberto. 1992. El español del Caribe. Madrid: MAPFRE.

Lunn, Patricia. 2002. "Tout se tient in Dominican Spanish". In J.F. Lee, K.L. Geeslin \& J.C. Clements (eds.), Structure, meaning, and acquisition in Spanish. Papers from the 4th Hispanic Linguistics Symposium, 65-72. Somerville: Cascadilla Press.

Marchello-Nizia, Christiane. 1999. Le français en diachronie: Douze siècles d'évolution. Paris: Ophrys.

Martínez-Sanz, Cristina. 2011. Null and overt subjects in a variable system: The case of Dominican Spanish. Ph.D. thesis, University of Ottawa.

Megenney, William W. 1985. "La influencia criollo-portuguesa en el español caribeño". Anuario de Lingüística Hispánica 1: 157-179.

Miró Vera, Ramona \& M. Angel de Pineda. 1990. "Determinación sociolingüística de la presencia/ausencia del pronombre personal sujeto". In M.T. Palet Plaja (ed.), Sociolingüística Andaluza 5: Habla de Sevilla y hablas americanas, 37-44. Sevilla: Servicio de Publicaciones de la Universidad de Sevilla.

Mondéjar, José. 1970. El verbo andaluz: formas y estructuras. Madrid: Consejo Superior de Investigaciones Científicas.

Morales, Amparo. 1986a. "Algunos aspectos de gramática en contacto: la expression del sujeto en el español de Puerto Rico". Anuario de Letras 24: 71-85.

Morales, Amparo. 1986b. "Estructuras sintácticas anglicadas en el español de Puerto Rico: Infinitivos y gerundios (análisis transformacional)". In A. Morales (ed.), Gramáticas en contacto: Análisis sintácticos sobre le español de Puerto Rico, 38-54. Madrid: Playor.

Morales, Amparo. 1997a. "Interacción de sintaxis y semántica en la variación dialectal: Los sujetos pronominales". Anuario de Lingüística Hispánica 11: 253-276.

Morales, Amparo. 1997b. "La manifestación del sujeto en español: tendencias universales y variación dialectal”. In R. Hammond \& M. MacDonald (eds.), Linguistic studies in honor of Bohdan Saciuk, 87-103. West Lafayette, IN: Learning Systems.

Morales, Amparo. 1999. "Anteposición del sujeto en el español del Caribe”. In L. Ortiz López (ed.), El Caribe hispánico: Perspectivas lingüísticas actuales. Homenaje a Manuel Alvarez Nazario, 77-98. Madrid: Vervuert.

Navarro Tomás, Tomás. 1929. "Impresiones sobre el estudio lingüístico en Puerto Rico". Revista de Estudios Hispánicos 2(2): 127-147.

Navarro Tomás, Tomás. 1948. El español en Puerto Rico. Contribución a la geografía lingüística hispanoamericana. Río Piedras: Editorial de la Universidad de Puerto Rico.

Núñez Cedeño, Rafael. 1983. "Pérdida de transposición de sujeto en interrogativas pronominales del español del Caribe". Thesaurus 38(1): 35-58.

Olloqui de Montenegro, Liliana de. 1984. "Un aspecto de la sintaxis: Los pronombres personales sujeto en el habla estudiantil santiaguera". Eme-Eme: Estudios Dominicanos 12(72): 3-17.

Ordóñez, Francisco. 2016. "Sujetos”. In J. Gutiérrez Rexach (ed.), Enciclopedia lingüística hispánica. Volumen 2, 101-110. London, NY: Routlegde.

Ordóñez, Francisco \& Esthela Treviño. 1999. "Left dislocated subjects and the pro-drop parameter: A case study of Spanish". Lingua 107(1-2): 39-68.

Ordóñez, Francisco \& Antxon Olarrea. 2001. "Weak subject pronouns in Caribbean Spanish and XP pied-piping”. In J. Herschensohn, E. Mallén \& K. Zagona (eds.), Features and interfaces in Romance. Essays in honor of Heles Contreras, 223-238. Amsterdam, Philadelphia: Benjamins.

Ordóñez, Francisco \& Antxon Olarrea. 2006. "Microvariation in Caribbean/non Caribbean Spanish interrogatives". Probus 18: 59-96. 
Ortiz López, Luis. 2009a. "El español del Caribe: Orden de palabras a la luz de la interfaz léxico-sintáctica y sintáctico-pragmática. Revista Internacional de Lingüística Iberoamericana 7(2): 75-93.

Ortiz López, Luis. 2009b. "Pronombres del sujeto en el español (L2 vs L1) del Caribe”. In M. Lacorte \& J. Lehmann (eds.), Español en Estados Unidos y otros contextos de contacto. Sociolingüística, ideología y pedagogía / Spanish in the United States and other contact environments. Sociolinguistics, ideology, and pedagogy, 85-110. Frankfurt a.M., Madrid: Vervuert \& Iberoamericana.

Ortiz López, Luis. 2016. "Dialectos del español de América: Caribe antillano (morfosintaxis y pragmática)”. In J. Gutiérrez Rexach (ed.), Enciclopedia lingüística hispánica. Volumen 2, 316-329. London, NY: Routlegde.

Otheguy, Ricardo. 1973. "The Spanish Caribbean: A creole perspective". In C.-J.N. Bailey \& R.W. Shuy (eds.), New ways of analyzing variation in English, 323-339. Washington, D.C.: Georgetown University Press.

Otheguy, Ricardo \& Ana C. Zentella. 2007. “Apuntes preliminares sobre el contacto lingüístico y dialectal en el uso pronominal del español en Nueva York". In K. Potowski \& R. Cameron (eds.), Spanish in contact. Policy, social and linguistic inquiries, 275-295. Amsterdam, Philadelphia: Benjamins.

Padrón, Alfredo F. 1948. "Giros sintácticos corrientes en el habla popular, culta y semiculta cubanas". Boletín de Filología 5: 467-495.

Padrón, Alfredo F. 1949a. "Comentarios de sintaxis cubana". Revista Bimestre Cubana 64: 195-210.

Padrón, Alfredo F. 1949b. "Giros sintácticos usados en Cuba”. Thesaurus 5: 34-48.

Patín Maceo, Manuel A. 1940. Dominicanismos. Ciudad Trujillo: Montalvo.

Peralta Céspedes, Manuel. 2017. "El español dominicano en contacto con el español madrileño: El caso del sujeto en las interrogativas directas". In C. Felbeck \& A. Klump (eds.), Dominicanidad / Dominicanity. Perspectivas de un concepto (trans-)nacional / Perspectives on a (trans-)national concept, 93-111. Frankfurt a.M. etc.: Lang.

Pérez Guerra, Irene. 1989. "Africanismos lingüísticos en República Dominicana. Notas metodológicas". In J.J. Montes Giraldo (ed.), Estudios sobre el español de América y lingüística afroamericana : Ponencias presentadas en el 45 Congreso Internacional de Americanistas, Bogotá, Universidad de Los Andes, 1-7 de julio, 1985, 354-368. Bogotá: Instituto Caro y Cuervo.

Pérez-Leroux, Ana Teresa. 1993. Empty categories and the acquisition of wh-movement. Ph.D. thesis, University of Massachusetts.

Pérez-Leroux, Ana Teresa. 1999. "Innovación sintáctica en el español del Caribe y los principios de la gramática universal”. In L.A. Ortiz López (ed.), El Caribe hispánico: perspectivas lingüísticas actuales. Homenaje a Manuel Álvarez Nazario, 99-118. Madrid: Iberoamericana.

Pérez Sala, Paulino. 1971. Estudio lingüístico de Humacao. Madrid: Partenon.

Pérez Sala, Paulino. 1973. Interferencia lingüística del inglés en el español hablado en Puerto Rico. Un estudio sobre la sintaxis de los puertorriqueños. Hato Rey: Inter American University Press.

Pöll, Bernhard. 2015. "Caribbean Spanish = Brazilian Portuguese? Some comparative thoughts on the loss of pro-drop". Studies in Hispanic and Lusophone Linguistics 8(2): 317-354.

Pollock, Jean-Yves. 1989. "Verb movement, universal grammar, and the structure of IP". Linguistic Inquiry 20(3): 365-424.

Quirk, Ronald J. 1972. "On the extent and origin of questions in the form ¿Qué tú tienes?". Hispania 55(2): 303-304. 
Ranson, Diana L. 1991. "Person marking in the wake of /s/ deletion in Andalusian Spanish". Language Variation and Change 3(2): 133-152.

Real Academia Española. 2009a. Nueva gramática de la lengua española. Morfología. Sintaxis I. Madrid: Espasa Libros.

Real Academia Española. 2009b. Nueva gramática de la lengua española. Sintaxis II. Madrid: Espasa Libros.

Rivas, Javier \& Esther L. Brown. 2011. "Correlaciones entre forma y función en las construcciones interrogativas parciales del español de Puerto Rico". Estudios de Lingüística Universidad de Alicante 25: 289-315.

Roberts, Ian. 1993. Verbs and diachronic syntax. A comparative history of English and French. Dordrecht: Kluwer.

Rodríguez-Izquierdo, Fernando. 1982. "Economía y redundancia en el uso de los sustitutos gramaticales". In P. Carbonero Cano (ed.), Sociolingüística andaluza 1. Metodología y estudios, 119-134. Sevilla: Universidad de Sevilla.

Sessarego, Sandro \& Javier Gutiérrez-Rexach. 2017. "Revisiting the null subject parameter: New insights from Afro-Peruvian Spanish". Isogloss 3(1): 43-68.

Silva-Villar, Luis. 1998. "Subject positions and the roles of CP”. In A. Schwegler, B. Tranel \& M. Uribe-Etxebarria (eds.), Romance linguistics. Theoretical perspectives. Selected papers from the 27th Linguistic Symposium on Romance Languages (LSRL XXVII), Irvine, 20-22 February, 1997, 247-270. Amsterdam, Philadelphia: Benjamins.

Skårup, Povl. 1975. Les premières zones de la proposition en ancien français. Essai de syntaxe de position. Copenhagen: Akademisk Forlag.

Solé, Yolanda R. \& Carlos A. Solé. 1977. Modern Spanish syntax. A study in contrast. Lexington, MA, Toronto: Heath.

Speas, Margaret. 1994. "Null arguments in a theory of economy of projection". University of Massachusetts Occasional Papers in Linguistics 17: 179-208.

Sprouse, Rex \& Barbara Vance. 1999. "An explanation for the decline of null pronouns in certain Germanic and Romance languages". In M. DeGraff (ed.), Language creation and language change: Creolization, diachrony, and development, 257-284. Cambridge, MA: The MIT Press.

Stiehm, Bruce. 1987. "Sintaxis histórica, dialectos de América y sintaxis natural". In H. López Morales \& M. Vaquero (eds.), Actas del I Congreso Internacional sobre el Español de América, San Juan, Puerto Rico, del 4 al 9 de octubre de 1982, 441-450. San Juan: Academia Puertorriqueña de la Lengua Española.

Suñer, Margarita. 1982a. "On null subjects". Linguistic Analysis 9(1): 55-78.

Suñer, Margarita. 1982b. Syntax and semantics of Spanish presentational sentence-types. Washington, D.C.: Georgetwon University Press.

Suñer, Margarita. 1983. "Proarb". Linguistic Inquiry 14(1): 188-191.

Suñer, Margarita. 1986. "Lexical subjects of infinitives in Caribbean Spanish". In O. Jaeggli \& C. Silva-Corvalan (eds.), Studies in Romance linguistics, 189-203. Dordrecht: Foris.

Suñer, Margarita. 1994. "V-movement and the licensing of argumental wh-phrases in Spanish". Natural Language and Linguistic Theory 12: 335-372.

Suñer, Margarita. 2003. "The lexical preverbal subject in a Romance null subject language. Where are thou?" In R. Núñez Cedeño, L. López \& R. Cameron (eds.), A Romance perspective on language knowledge and use. Selected papers from the 31st Linguistic Symposium on Romance Languages (LSRL), Chicago, 19-22 April 2001, 341-358. Amsterdam, Philadelphia: Benjamins.

Suñer, Margarita \& Carmen Lizardi. 1995. "Dialectal variation in an argumental/nonargumental asymmetry in Spanish". In J. Amastae, G. Goodall, M. Montalbetti \& M. Phinney (eds.), Contemporary Research in Romance Linguistics. Papers from the 22nd 
Linguistic Symposium on Romance Languages El Paso/Cd. Juárez, February 1992, 187203. Amsterdam, Philadelphia: Benjamins.

Terrell, Tracy. 1982. "Relexificación en el español dominicano: Implicaciones para la educación". In O. Alba (ed.), El español del Caribe, 301-318. Santiago: Universidad Católica Madre y Maestra.

Ticio, M. Emma. 2004. "On the position of subjects in Puerto Rican Spanish". University of Connecticut Working Papers in Linguistics 12: 78-92.

Toribio, Almeida J. 1993. "Lexical subjects in finite and non-finite clauses". Cornell Working Papers in Linguistics 11: 149-178.

Toribio, Almeida J. 2000a. "Minimalist ideas on parametric variation". In M. Hirotani, A. Coetzee, N. Hall \& J. Kim (eds.), Proceedings of the North East Linguistic Society 30. Volume 2, 627-638. Amherst: University of Massachusetts.

Toribio, Almeida J. 2000b. "Setting parametric limits on dialectal variation in Spanish". Lingua 110(5): 315-341.

Torrego, Esther. 1984. "On inversion in Spanish and some of its effects". Linguistic Inquiry 15(1): 103-129.

Vance, Barbara. 1995. "On the clitic nature of subject pronouns in Medieval French". In A. Dainora, R. Hemphill, B. Luka, B. Need \& S. Pargman (eds.), CLS 31. Papers from the 31st regional meeting of the Chicago Linguistic Society. Volume 2: The parasession on clitics, 300-315. Chicago: Linguistic Society.

Vance, Barbara. 1997. Syntactic change in Medieval French. Verb-second and null subjects. Dordrecht: Kluwer.

Zamora Munné, Juan C. \& Jorge M. Guitart. 1988. Dialectología hispanoamericana. Teoríadescripción - historia. Salamanca: Colegio de España.

Zimmermann, Michael. 2014. Expletive and referential subject pronouns in Medieval French. Berlin, Boston: De Gruyter.

Zimmermann, Michael. 2016. "The status of subject pronouns in Modern Standard French revisited". In E. Carrilho, A. Fiéis, M. Lobo \& S. Pereira (eds.), Romance Languages and Linguistic Theory 10. Selected papers from 'Going Romance' 28, Lisbon, 305-324. Amsterdam, Philadelphia: Benjamins.

Zimmermann, Michael. 2018a. "Changes in status and paradigms? On subject pronouns in Medieval French". Transactions of the Philological Society 116(1): 131-149.

Zimmermann, Michael. 2018b. "Null subjects, expletives, and the status of Medieval French". In F. Cognola \& J. Casalicchio (eds.), Null subjects in generative grammar. A synchronic and diachronic perspective, 70-93. Oxford, NY: Oxford University Press.

Zubizarreta, Maria L. 1999. "The Cl(itic) Projection in questions". Catalan Working Papers in Linguistics 7: 253-277. 